Reading Research Quarterly, 44(1)

2009

\title{
Damsels in Discourse: Girls Consuming and Producing Identity Texts Through Disney Princess Play
}

Karen Wohlwend

Indiana University

\section{Abstract}

Drawing upon theories that reconceptualize toys and artifacts as identity texts, this study employs mediated discourse analysis to examine children's videotaped writing and play interactions with princess dolls and stories in one kindergarten classroom. The study reported here is part of a three-year ethnographic study of literacy play in U.S. early-childhood classrooms. The specific focus here is on young girls who are avid Disney Princess fans and how they address the gendered identities and discourses attached to the popular films and franchised toys. The study employs an activity model design that incorporates ethnographic microanalysis of social practices in the classroom, design conventions in toys and drawings, negotiated meanings in play, and identities situated in discourses. The commercially given gendered princess identities of the dolls, consumer expectations about the dolls, the author identities in books and storyboards associated with the dolls, and expectations related to writing production, influenced how the girls upheld, challenged, or transformed the meanings they negotiated for princess storylines and their gender expectations which influenced who participated in play scenarios and who assumed leadership roles in peer and classroom cultures. When the girls played with Disney Princess dolls during writing workshop, they animated identities sedimented into toys and texts. Regular opportunities to play with toys during writing workshop allowed children to improvise and revise character actions, layering new story meanings and identities onto old. Dolls and storyboards facilitated chains of animating and authoring, linking meanings from one event to the next as they played, wrote, replayed, and rewrote. The notion of productive consumption explains how girls enthusiastically took up familiar media narratives, encountered social limitations in princess identities, improvised character actions, and revised storylines to produce counter-narratives of their own. 
Reading Research Quarterly, 44(1)

2009

Childhood cultures are made up of interwoven narratives and commodities that

cross TV, toys, fast-food packaging, video games, T-shirts, shoes, bed linen, pencil cases, and lunch boxes...teachers find their cultural and linguistic messages losing power and relevance as they compete with these global narratives. Just how do we negotiate these invasive global texts?

—(New London Group, 1996, p. 70)

In a global array of children's merchandise and playthings, the Disney Princess ${ }^{\mathrm{TM}}$ franchise stands out. The Disney Princess brand, "the most successful property for Disney Toys" (Disney Consumer Products, 2007, đ[3), brings together eight heroines from Walt Disney Pictures’s animated film classics: Snow White, Jasmine from Aladdin, Belle from Beauty and the Beast, Pocahontas, Mulan, Cinderella, Arielle from The Little Mermaid, and Aurora from Sleeping Beauty. Young girls, ages 3 to 5 years old, are the target market for Disney Princess multimedia and an accompanying line of licensed toys, collectibles, apparel, and household goods featuring the film characters. The entire franchise produced $\$ 4$ billion in global retail sales for 2007, offering a bedazzling collection of pastel products that includes animated films, DVDs, toys, fast food meals, music CDs, books, interactive web pages, video games, costumes, clothing, bed linens, school supplies, makeup kits, and even Cinderella cleaning supplies (Iger, 2006; Noon, 2005).

Identity messages circulate through merchandise that surrounds young consumers as they dress in, sleep on, bathe in, eat from, and play with commercial goods decorated with popularculture images, print, and logos, immersing children in products that invite identification with familiar media characters and communicate gendered expectations about what children should buy, how they should play, and who they should be (New London Group, 1996). During play 
Reading Research Quarterly, 44(1)

2009

with Disney Princess toys, children re-enact film scripts and expectations for each princess character, quoting memorized dialogue or singing songs from the films as they talk in-character while playing with dolls or while using princess accessories. The pervasive availability of consumer products associated with the Disney Princess films blurs the line between play and reality, allowing children to live in-character: One can be Cinderella all day long, sleeping in pink princess sheets, eating from lavender Tupperware ${ }^{\mathrm{TM}}$ with Cinderella decals, and dressing head to toe in licensed apparel, from plastic jewel-encrusted tiara to fuzzy slipper-socks.

Fascination with Disney royalty also travels to school, toted in pink backpacks and lunchboxes decorated with large smiling princess heads. In some classrooms, popular-culture media and toys are relegated to the unofficial space of the playground, deemed inappropriate topics for the serious business of learning to read and write. However, in classrooms with permeable curricula (Dyson, 1993), children selectively choose material from their popularculture repertoire for literacy play themes (Dyson, 1997, 2003). In the classroom case in this article, a permeable curriculum incorporated Disney Princess dolls and stories into writing workshop activities, enabling children to replay and rewrite the well-worn storylines and characters from Disney films and to use princess themes to fuel their passions and impress their peers.

This article examines kindergartners' play with Disney Princess dolls and stories to discover how young girls read and respond to constraining storylines attached to their beloved media toys. (The focus of this article is on the girls' play and writing with Disney princesses and associated discourses. A thorough discussion of the boys who also played, wrote, and clearly loved these films is beyond the scope of this article and is the focus of a separate article [Wohlwend, 2008].) 
Reading Research Quarterly, 44(1)

2009

Do girls enthusiastically take up and replay stereotypical gendered narratives evoked by dolls or do they revise stories and characters to produce counternarratives of their own? Analysis of excerpts from a three-year ethnographic study of literacy play in kindergarten classrooms shows that when girls played with Disney Princess dolls and repeatedly enacted the associated film texts, they rewrote plots they knew by heart and subtly altered character roles to take up more empowered identity positions in child-ruled imaginary spaces. As they wrote plays and books about Disney Princess characters, children drew upon their media knowledge as well as valued school literacy practices (Street, 1995) and available classroom identities as girls and boys, authors and animators, and actors and directors. In this article, I examine recursive processes of improvisation and revision in children's play and writings with Disney Princess dolls to understand how toys act as durable texts that concretize identities and discourses (my use of the term discourse is consistent with Gee's [1996] use of the term as particular ways of talking, speaking, dressing, playing, etc., that index affiliation with a larger group or set of beliefs. Because these ways simultaneously index a group's beliefs and tacit rules, I also use discourse in a Foucauldian sense to indicate how language circulates power in global and local ways. When I refer to specific verbal interactions, I will use such terms as talk or speech) in media narratives as well as children's counternarratives. More specifically:

How do young girls combine play and writing to negotiate the tension between their desire to faithfully reproduce storylines from favorite Disney films and their desire to get past social limitations of performing the predetermined gender expectations associated with media toy marketing and princess play?

What happens when teacher acceptance of Disney Princess dolls as appropriate materials for writing workshop juxtaposes character and consumer identities in femininity 
Reading Research Quarterly, 44(1)

2009

discourse with authoring identities in discourses of creative expression and learner agency?

\section{Review of Research: Identity Texts in Dolls, Discourses, and Social}

\section{Practices}

\section{Reading Artifacts as Identity Texts}

All cultural artifacts, from children's scribbled drawings to manufacturers' franchised toys, bear traces of the social practices that produced them (Brougère, 2006). Jennifer Rowsell and Kate Pahl (2007) combined theories of text with sociocultural theories of identity (Gee, 1996; Holland, Lachicotte, Skinner, \& Cain, 1998) to read child-made artifacts as tangible links to children's identities and histories of experiences. An artifact can be read for its producer's intended meaning and also for its sedimented identities, layers that reflect a child's decisions about which modes and materials to use (Kress, 1997, 2003b), the identity performances made available to children within prevailing discourses (Butler, 1993), and the practices and dispositions, or habitus valued by families, schools, or communities (Bourdieu, 1977). This expanded definition of texts in context recognizes drawings, crafts, and art projects as literacy artifacts, fashioned from material objects with physical properties and design affordances that can be read as layered assemblages of meanings, modes, practices, histories, and discourses.

The conflation and intersection of Discourses become modalities in texts, which, alongside practices, provide a formative picture of the meaning makers - not only their pathway into literacy but also how they make meaning in certain contexts and engage in practice. The theory provides a lens on how producers sediment identities and what identities they sediment. (Rowsell \& Pahl, 2007, p. 392, emphasis in original) 
Through ethnographic analysis, Rowsell and Pahl uncovered evidence that children's artifacts hold traces of literacy practices that tap into prior experiences and sedimented layers of identities, social practices, and dispositions learned at home and school. For one child, making a bird from tissue paper layered his knowledge of chickens on his family's farm in rural Turkey, a pet name that his mother had for him, a teachers' reading of The Ugly Duckling, and a prior birdmaking craft activity at school. His hand-made artifact concretized the previous as well as the immediate social practices used to create them. "The text, then, becomes an artifact of identities as much informed by social practice, habitus (Bourdieu, 1977), and context as it is by the material choices made during its creation” (Rowsell \& Pahl, 2007, p. 392).

This article extends Rowsell and Pahl's (2007) notion of artifacts as sedimented identities in texts deposited by layered histories of multimodal literacy practices. I suggest that commercially produced toys are artifacts with anticipated identities: identities that have been projected for consumers and that are sedimented by manufacturers' design practices and distribution processes. Anticipated identities in toys and commercial media that children consume interact in tensionwith sedimented identities in artifacts that children produce through literacy practices in peer and classroom cultures. The findings reported in this article suggest that literacy play is an important means for accessing and reproducing anticipated identities and for improvising and sedimenting revised identities into their toys and writings in ways that enrich and constrain children's play performances with consequences for their social standing among peers.

\section{Toys as Identity Texts, Children as Consumers and Players}

In the round-the-clock montage of licensed consumer products for children, toys represent a special kind of child-oriented text. A toy is a text specifically designed to enable children to 
Reading Research Quarterly, 44(1)

2009

easily recognize the ways it can be used in play (Brougère, 2006). Toys that are associated with children's popular animated films or television programs encourage children to play and replay familiar scripts and character roles. These media toys act as multilayered texts that call forth "possible worlds" (Luke, Carrington, \& Kapitzke, 2003) that set literary limits and social boundaries for character roles, dialogue, and storylines. On one level, Disney Princess toys inspire children to replay remembered plots and recite memorized scripts, providing explicit narratives that shape children's play; on another level, the film scripts and characterizations convey more subtle narratives about identity and status that relate to global markets and societal beliefs about gender and childhood.

In this expanded definition, toys invite players to read and perform particular identities through play. Victoria Carrington (2003) analyzed Diva Starz ${ }^{\mathrm{TM}}$ dolls as texts in the context of a "textual landscape" that merges consumer expectations in global markets and gender expectations in popular media. These talking dolls communicate a "hip" quality through their materials as well as their prerecorded one-liners. The dolls' material design updates the classic Barbie $^{\mathrm{TM}}$ design by adding Japanese anime facial features: nonexistent ears, tiny nose and mouth, and enormous eyes that cover one third of the face. The identity text "cool girl" is communicated through the doll's anime features as well as its hairstyle, makeup, and clothing. The doll's snippets of talk, “I'm bored—Let's go shopping," voice gendered consumer identity messages for children in the target demographic of 6- to 12-year-old girls. Carrington's analysis interrogates these popular dolls as complex texts that require children as readers, players, and consumers to coordinate messages about taste, cultural capital, and social status (Bourdieu, 1986). 
Reading Research Quarterly, 44(1)

2009

It is incumbent upon us, then, to examine the kinds of messages these dolls send to our girlchildren as they interact with them. They are clearly not printed texts. Instead, the Divas are powerful markers of the necessary expansion of the notion of "text" in contemporary postindustrial societies and, more specifically, in discussions around literacy. (Carrington, 2003, p.

I suggest that Disney Princess dolls also "talk," not through prerecorded audio but through their sedimented film plots, scripts, and songs. The dolls index identity texts from damsel-in-distress fairy tales with princess victims and princely rescuers, a classic trope in children's literature and play that "prepare[s] the ground for the insertion of the little girl into romantic heterosexuality" (Walkerdine, 1984, p. 163). Some researchers in childhood studies who examine identity expectations in popular-culture media and toys (Steinberg \& Kincheloe, 1997) have contended that Disney animated fairy tales reduce heroines to happy homemakers-in-waiting. For example, girls are often portrayed as dependent and innocent (with sexual undertones) ingénues waiting for a royal husband as life's fulfillment (Do Rozario, 2004). Older women are either backgrounded as loving (preferably deceased) mothers (Haas, 1995) or, if powerful and independent, vilified as evil femme fatales or ugly hags (Bell, 1995; Christensen, 2000; Giroux, 1997, 1999). However, media studies and ethnographies of children's actual responses to popular culture problematize characterizations of children as media victims and cultural dupes, finding more critical awareness and agency in the complicated relationship between children and popular media (Buckingham, 1996; Davies, 1989; Dyson, 1997, 2003; Marsh, 2006; Seiter, 1993; Tobin, 2000, 2004). 
Reading Research Quarterly, 44(1)

2009

\section{Identity Texts and Gender Discourses in Children's Princess Play}

As a telling case (Mitchell, 1984), princess play illustrates how children read and respond to gendered narratives as they play and write stories. Feminist poststructuralist researchers have found that princess identity texts "engage with the production of girls' conscious and unconscious desires, prepare for and proffer a 'happy every after' situation in which the finding of the prince (the knight in shining armour, 'Mr. Right') comes to seem like a solution to a set of overwhelming desires and problems" (Walkerdine, 1984, p. 163). From classic books to popular media, the consistent requirement for any princess is that she must be beautiful (Baker-Sperry \& Grauerholz, 2003). The princess ideal is the archetype in a pervasive cultural norm of feminine beauty, a kind of gendered talk that Mindy Blaise (2005b) identified in a year-long ethnographic study of gender discourses in a U.S. public school kindergarten. Critical discourse analysis of play activity showed that children regulated each other's gender performances through talk and actions that demonstrated their ability to adhere to the heterosexual matrix (Butler, 1993) that “regulates gender and gender relations so that heterosexuality becomes the 'normal,' right, and only way to be" (Blaise, 2005b, p. 22). For girls, gendered talk included the following: "wearing femininity, body movements [e.g., twirling (hair or skirt), curtseying], make-up, beauty, and fashion talk" (Blaise, 2005a, p. 85, italics in original). During princess play, girls focused on achieving beauty ideals and rejected play scenarios that stretched stereotypical male/female roles. Blaise found princess play to be a prime site for gender performances:

The value that a small group of girls placed on being beautiful and pretty became evident in the dramatic play area while they were pretending to be princesses.... Often, early childhood teachers and parents view children's pretend play as "simply play," failing to recognize how gender is created and re-created in these story lines. As children enact the storylines of princes and 
Reading Research Quarterly, 44(1)

2009

princesses, the importance of being pretty and the role it plays in creating femininities and masculinities provide another opportunity for locating the heterosexual matrix in the classroom. (Blaise, 2005b, p. 77)

Bronwyn Davies (1989) found strong attachment to princess identity texts and gendered discourses when she studied young children's reactions to feminist versions of classic fairy tales (e.g., The Paper Bag Princess, Munsch, 1980). Davies interviewed and observed preschoolers in four Australian early-childhood centers, finding that children often rejected revisionist stories of brave princesses and gentle princes, at times vehemently. Children committed socially and emotionally to a dualistic model of male and female roles as they actively constructed and performed gender in their fantasy play and storytelling as well as in everyday classroom interactions. Other feminist poststructural researchers have corroborated children's persistent maintenance of gender roles during play (Boldt, 2002; Maclean, 1999) and in early writing (Kamler, 1994). In an article entitled "Princesses Who Commit Suicide," Laurie MacGillivray and Ana Maritza Martinez (1998) used a Foucauldian lens to analyze 13 princess stories written by children in a multiage primary classroom. In their stories, children did not attempt to disrupt gender stereotypes: Girls as well as boys positioned male characters as powerful and female characters as weak, even suicidal, victims. However, few studies have used the fine-grained lens of microethnographic analysis (Bloome, Carter, Christian, Otto, \& Shuart-Faris, 2005) to examine children's princess play practices and texts, an approach that could discern more subtle alterations in traditional character roles and storylines by the most avid princess players. 
Reading Research Quarterly, 44(1)

2009

\section{Theorizing Toys as Texts and Literacy Play as Nexus of Practice}

\section{Toys and Social Semiotics}

Among cultural artifacts, toys are unique. Toys must communicate meanings that appeal to children to be taken up and must be malleable enough to allow players to invent new meanings; that is, toys invite a particular meaning and simultaneously enable its revision (Brougère, 2006). In this article, I propose an expanded notion of toys as literacy objects: A toy is (a) a text to be read, performed, and consumed with meanings suggested by its materials and its history of attached storylines and practices and (b) a text to be written, produced, and revised as children improvise new meanings through play. This closer look at materials considers commercially manufactured designs and a priori storylines as concretized texts embedded in toys that affect the ways players enact characters and plots.

Toys communicate through the physical properties of their materials and their associated histories of use. Materials have iconic meanings: For example, the velvety fleece covering of a stuffed doll sends one message, whereas the sparkly metallic finish of a fashion doll's tiara sends another. In Peircian (Hartshorne, Weiss, \& Burks, 1998) semiotics, iconicity allows objects or words to transmit meanings by evoking a sensory quality; the stuffed doll is an icon of softness. This doll may also index, or point to nonpresent experiences or ideas that recall, caregiving and comfort in a child's familial experiences. Through its iconic softness and its indexed history of nurture, the fleece doll communicates "cuddle me" to a young child. It is a sign, a form (in this case, a toy doll) that stands for something else (iconic softness and indexed nurturing) and the sense that is made of it (cuddling activity).

Children are highly aware of the material meanings of toys and their sign-making potential (Kress, 1997, 2003b). When children play together, they assign, negotiate, and maintain 
Reading Research Quarterly, 44(1)

2009

symbolic pretended meanings for objects consistent with the imagined setting. At times, these negotiations occur outside the play frame (Bateson, 1955/1972) through language that distinguishes the real activity from the not-real activity through explicit talk that assigns play meanings to props. Vygotsky’s (1934/1978) example of a child pretending that a stick stands for a horse exemplifies the symbolic substitution achieved through play. Thus, one child's proposal that a hard plastic Barbie become the baby sister of a stuffed Cinderella doll can cause players to stop playing to negotiate tensions between the dolls' contrasting iconic material qualities and associated indexed identity texts about adults, babies, and siblings that conflict with the pretend identities that the children want to symbolize with the dolls.

Play actions that are consistent with children's agreed-upon text/context sustain and build players' shared meanings, whereas play actions that are incongruous with imagined characters or contexts challenge or alter the direction of play. Such contradictory play meanings spark the negotiations and improvised solutions that characterize children's fantasy play (Sawyer, 1997). Improvisation is an agentic response with the facility to creatively resolve dilemmas caused by competing discourses and to reconcile conflicting identity expectations (Holland, Lachicotte, Skinner, \& Cain, 1998). Through improvisation, children innovatively combine available practices, materials, and modes, often in unexpected ways, to accomplish their social goals.

A view of literacy play as multimodal (Jewitt \& Kress, 2003; Kress, 2003a) meaningmaking explains how signs are affected by combined practices, materials, or modes. Each language and literacy practice involves a primary modality: Talking involves auditory modes including speech and sound-effect; reading, writing, and artistic design involve visual modes including image and gaze; and play involves action modes including gesture and manipulation of objects. By combining writing with drawing, coloring, painting, cutting, singing, and enacting, 
Reading Research Quarterly, 44(1)

2009

children extend the meanings of their designs and move a single sign across several modalities

(Kress, 1997, 2003b). Sign-making is multimodal and motivated, influenced by the materials at hand and a child's interest (Kress, 1997). Rowsell and Pahl (2007) interpreted interest as more than an immediate intended meaning or social use; interest also includes the indexed histories of identities, practices, and dispositions that have been sedimented into the artifact during its production.

\section{Playing, Writing, and Mediating in Nexus of Practice}

The recognition that dolls are multimodal identity texts with anticipated identities, corporate roots, and global distribution prompts the need to examine the power relations and gender discourses in children's play practices and identity performances with toys. Ron Scollon's (2001b) notion of nexus of practice - a community's intricate web of tacit insider practices, expectations, and dispositions — combines Vygotskian mediation with Bourdieu's (1977) theory of practice to explain how language, culture, and material and social histories produce practices and identities. As girls play with dolls or write stories in school, they use objects to mediate- to alter to make more accessible - the surrounding social and material environment (Vygotsky, 1934/1978). These mediated actions (Wertsch, 1991) involve physical manipulation of objects: turning the pages of a book, moving a pencil to make marks on a paper, or handing a folded paper to someone. Mediated actions are made culturally meaningful when they are categorized as social practices (e.g., book-handling, copying a word, or giving a friend a birthday card) within the local network of practices valued among a group of people.

Each social practice is embedded within several simultaneous contexts: personal appropriation, cultural meaning-making, social histories of participation, and material histories of object/tool use and access (Wohlwend, 2007c). As children learn to handle materials and 
Reading Research Quarterly, 44(1)

2009

cultural tools, they learn which social practices are valued ways of participating (Rowe, 2008)

within an embodied community of practice (Lave \& Wenger, 1991). These social practices become engrained and automatic in each individual's habitus.

When certain practices regularly occur together, their combination comes to be expected as natural and part of group habitus, the familiar dispositions and everyday ways of interacting that community members expect from one another. When these combined practices also strengthen each other and produce social effects of importance to the community, they form nexus that are implicitly required of all members (Scollon, 2001b). Nexus of valued practices act as tacit markers of membership so that individuals who can perform expected combinations easily and automatically are instantly recognized as legitimate members of the community. In communities of practice (Lave \& Wenger, 1991), novices are provided with explicit demonstrations to help them learn valued combinations. For example, as part of their schooling, children are taught the ways of writing and of behaving that are valued and expected in their particular classroom culture (e.g., printing neatly and working quietly). As multiple nexus overlap and interact, a nexus of practice is created (Scollon, 2001b). This nexus of practice constitutes the valued routines and student expectations in the official spaces of a classroom and links to societal discourses about childhood.

However, children also create their own insider practices by using play spaces to produce nexus that are valued by other children (Wohlwend, 2007a). Children use play to form affiliations in the local peer culture (Corsaro, 1985, 2003) where they strategically use popular media as cultural capital (Dyson, 2003; Marsh, 2002). Cultural capital has social value specific to a particular group of people in a local situation just as material capital has general economic value that transcends the immediate cultural context and enables trade in the marketplace 
Reading Research Quarterly, 44(1)

2009

(Bourdieu, 1986). For example, the value of a toy varies from classroom to classroom and from one group of children to the next; the desirability of a toy may depend upon its scarcity in a classroom, its popularity in popular culture, or its sanction by the teacher. As cultural capital, toys also serve as entry vehicles into play groups, so that possession of a desired toy allows children to secure a role in fantasy play scenarios (Fernie, Kantor, \& Whaley, 1995).

Children who value the same toys and who choose to play together based upon their common interests create an affinity group (Fernie et al., 1995) through their shared preferences and activities. Within the focal classroom in this study, several affinity groups loosely coalesced over the course of the school around shared play themes. In this article, I focus on one affinity group: the Disney Princess Players who animated small dolls as they enacted stories and authored books about Sleeping Beauty and other princess characters. Kindergartners in this group used playing and writing practices with dolls, storyboards (comic-strip-like panels used by filmmakers to sketch out plot and character actions scene by scene), scripts, and books to participate in various school-expected ways of writing to accomplish varied purposes: for example, to produce play performances that were personally satisfying, to get recognized as an accomplished kindergarten writer by reading a script from the author's chair, or to impress other Disney Princess Players with one's knowledge of Little Mermaid lore.

\section{$\underline{\text { Research Design }}$}

A critical sociocultural approach to literacy research (Lewis, Enciso, \& Moje, 2007) provides a model for critically examining multiple facets of literacy practices, demonstrating that the explanatory power of discourse analysis is strengthened when framed by cultural-historical activity (Leont'ev, 1977; Vygotsky, 1934/1978) and informed by cultural studies. In the current research, I adapted an activity model design (Engeström, 1987) to coordinate theories of social 
Reading Research Quarterly, 44(1)

2009

practice, texts, and identities: mediated discourse (Scollon, 2001b), social semiotics (Hodge \&

Kress, 1988), cultural studies of media (Giroux, 1999; Jenkins, 1998), and feminist

poststructuralist perspectives on girlhood (Blaise, 2005a, 2005b; Davies, 1989). The combined

theories provide a multidimensional explanation of literacy play as mediated activity with commercial toys and child-made artifacts through which children access, animate, and author identity texts. The research design enabled mediated discourse analysis (Norris \& Jones, 2005; Scollon, 2001a; Scollon \& Scollon, 2004) of dynamic relationships between practices, materials, and discourses within nexus of practice to understand how children (social actors) use writing and play to transform material objects into designed products through mediated actions that are interpreted as social practices according to local histories in an embodied community of practice and its valued discourses.

\section{Method}

\section{Participants and Research Context: Disney Princess Players}

This article analyzes literacy play in a kindergarten classroom with 21 students and 1 teacher in a public elementary school in a university community in the midwestern United States. The kindergarten teacher, Abbie Howard, had 17 years of early-childhood classroom experience and a master's degree in developmental reading. Each morning, Abbie and the children negotiated a plan for the day, adjusting the schedule to include activities that the children suggested.

Following the opening meeting, children worked on self-selected projects that included writing and play during three consecutive 45-min activity periods-literacy choices, writing workshop, and choice-time centers. For example, during writing workshop, Abbie asked the children about their plans for writing and drawing stories as they trickled off to work on projects they had collected in their writing folders. Children worked independently as Abbie circulated and 
Reading Research Quarterly, 44(1)

2009

conferenced with children individually or in small groups. Each activity period was followed by a short class meeting during which children shared their projects as they perched, legs dangling, in the oversized wooden rocker that served as the author's chair.

In this class of 5- and 6-year-olds, affinity groups were fluid, with children joining and leaving groups throughout the morning as they followed their play interests. Across the span of months, however, consistent patterns of favorite content themes and preferred activities emerged. For coding purposes, I named the groups according to these shared interests, incorporating the children's language: Abbie Wannabes, a group of boys and girls who negotiated "I wanna be teacher" and enacted the role of teacher as they read books and played school together. Another group, all boys, Just Guys, explored art materials and design tools — in their words — by “just playin' around" as they drew pictures, constructed paper airplanes and toys, and reenacted local university football games. In this article, I focus on a third group, Disney Princess Players, comprised of girls and boys who animated small dolls as they enacted stories and authored books and plays about princess characters. The children's animations and writing activity frequently drew upon Disney Princess films for their characters and storylines, including The Little Mermaid, Sleeping Beauty, Mulan, Aladdin, Cinderella, and Snow White.

The group members included three girls, Zoe, Mei Yu, and Clare, and two boys, Nicholas and Peter (all names are pseudonyms). All the children in this group have transnational backgrounds and family members in other countries: China (Zoe, Mei Yu), the Philippines (Clare), and Russia (Peter, Nicholas). All the Disney Princess Players spoke English at school but said that they could speak another language as well, although Mei Yu was the only one who demonstrated this. The five children experienced tensions in their Disney Princess play that conflicted with family cultural values and contradicted peer gender expectations: For the Chinese American girls in the 
Reading Research Quarterly, 44(1)

2009

group, the characterizations of evil or comical dragons in Sleeping Beauty and Mulan conflicted with family values and cultural traditions that revered dragons, and for the boys in the group, enthusiastic doll play resulted in teasing from other boys in the class. For the purposes of this article, I focus on the three girls and the gendered tensions that arose during their playing and writing as they struggled with the consumption and production of identity texts and discourses.

\section{Data Collection and Analysis}

\section{Surveying sites and participants}

Following case study methodology (Dyson \& Genishi, 2005) and purposive sampling procedures (Merriam, 1998), I asked knowledgeable informants in three school districts to recommend specific classrooms with child-directed literacy-play periods. During three school years, I visited, observed, and photographed eight classrooms in three schools. Discussion among a focal group of kindergarten teachers clarified and highlighted local issues, institutional barriers, and teachers' instructional beliefs about literacy play (Wohlwend, 2007b). To identify a classroom rich in material resources for literacy and play, I analyzed materials in the eight kindergartens using literacy environment surveys (Loughlin \& Martin, 1987; Wolfersberger, Reutzel, Sudweeks, \& Fawson, 2004) and a play environment checklist that I had developed to examine the physical products, tools, and material objects that were actually used by the children in the selected classrooms. I conducted pilot studies in two of the kindergarten classrooms to locate the times and spaces that integrated play, literacy, and design activity (Wohlwend, 2008).

After identifying Abbie Howard's kindergarten for case study, I visited the classroom 24 times, approximately once a week during one school year excluding parent-teacher conference days, testing days, and the last month of school due to a schoolwide project. Visits lasted from 2 to three hr, primarily during the mornings during play-integrated periods. As a participantobserver, I videotaped, took field notes, and worked at tables with the children, participating in 
Reading Research Quarterly, 44(1)

2009

projects as necessary in a classroom where children expect adults to be helpful (Toohey, 2000).

Consistent with principles of ethnographic research and methods of mediated discourse analysis

(Norris \& Jones, 2005; Scollon, 2001a; Scollon \& Scollon, 2004), data were regularly cross-

checked against members' views, researcher observations, individual cases that confirmed or

disconfirmed findings, and recursive analysis of previously collected data, increasing validity through triangulation (Merriam, 1998).

\section{Observation of locations for focal practices}

In the first weeks in Abbie Howard's classroom, I observed the literacy and play center locations where children played, drew, wrote, and read. I checked my initial frequency counts of observed practices against the children's reports of their favorite locations, companions, and activities. Sociograms and maps organized and triangulated data from children's reports, my field notes, and video data. For example, the Disney Princess Players' video data corroborated Zoe's report that she liked to play with Nicholas (42\% of observed days). However, video data also showed that Zoe interacted more often with Mei Yu (37\%) than she did with Peter (21\%) and more frequently with Clare (58\%) than with anyone else.

\section{Tracking key practices to identify nexus}

Analysis of videotaped activity located the particular combinations that constituted nexus of mutually strengthening reading, writing, design, or play practices that occurred most frequently in a particular area. I created a coding scheme supported by NUD*IST 6 (Richards \& Richards, 2002), a qualitative coding software, and ran searches for intersections of coded practices by affinity groups to identify nexus. After Disney Princess Players emerged as a focal group with writing/playing as a focal nexus, I regularly recorded this affinity group's activity (69 total recorded instances). For frequency counts and coding purposes, an instance consisted of observed activity with a set of objects (e.g., crayons, markers, storyboards, dolls, or doll 
furniture) among children in a location (e.g., at the writing table or at the dollhouse) from the first child's arrival until the last child left.

An electronic portfolio of digital photographs, coding schemes, maps and diagrams, audio files, and organizational spreadsheets cataloged data sources and enabled quick retrieval and comparison of data. More important, the files comprised an audit trail that could be traced through spreadsheets that coordinated data sources and enabled cross-referencing of emerging patterns against the software program's coding reports, multiple drafts of coding schemes, expanded field notes files, and research journal. An overarching spreadsheet summarized the data and chronicled the coding progress and evolution as I marked the date, the text unit reference number to locate the coded data in the software program, and rationale behind each coding revision. As I constantly compared data, this trail allowed me to look back over the conscious choices I had made that affected patterns in the analysis, making assumptions visible and traceable. Electronic organization of data helped identify key locations and practices during the first month of school and allowed more focused data collection on focal groups of children, such as the Disney Princess Players.

\section{Locating key events for microanalysis}

Key events were coded instances in which (a) writing inspired play improvisations and (b) play produced writing revisions. Microethnographic methods of discourse analysis (Bloome et al., 2005) tracked verbal and nonverbal interactions between children as they manipulated tools, materials, and toys. For example, children not only talked to each other as they played with toys or drew stories; they also talked about, through, or to objects (e.g., to redefine a dollhouse baby crib as a flying Cinderella coach, to animate a drawing of a bewitched Princess Aurora, or to coax a too-small puppet over one's hand). I developed a transcription scheme using a table format to record each turn (row) and its constitutive elements (columns): (a) interactional turn; 
(b) time; (c) context with children's actions, body positions, and manipulation of objects; (d) talk at each turn; (e) classroom identities; (f) play identities; (g) writing and play practices; (h) the meanings of texts and toys; and (i) classroom participation.

Meaning revisions in the girls' drawings, writings, and storyboards were tracked through visual analysis of images and artifacts (Jewitt \& Oyama, 2001) to corroborate events with transformational social effects. Social semiotic theory (Hodge \& Kress, 1988) interprets images and objects in terms of visual design elements and prevailing conventions for visual composition situated in power relationships (Kress \& van Leeuwen, 1996; van Leeuwen \& Jewitt, 2001). Visual analysis enabled inspection of children's drawn images and artifacts for strategic uses of design conventions: expectations that shape the interpretation of design elements (line, shape, size, texture, color, value, and direction) and use of design principles (balance, repetition, gradation, harmony, dominance, contrast, and unity). Triangulating visual analysis of girls’ writing with microanalysis of physically mediated actions with objects (e.g., bouncing a doll, pointing to a story board, pushing an actor, wielding a cardboard sword) and interactional analysis of children's conversational moves (e.g., interrupting, proposing, affirming, rejecting, ignoring) revealed links to gendered identity texts in discourses of femininity that constrained children's performances of play identities as princesses or princes as well as their daily classroom identities as students and peers.

\section{Animating and Authoring Identity Texts in the Playing/Writing Nexus}

\section{Animating Dolls, Identities, and Discourses}

\section{Key practice: Animating}

Almost half of the Disney Princess Players' observed activity (48\% of 69 total coded events for this group) involved the play practice animating, moving and speaking for dolls or other toys as 
Reading Research Quarterly, 44(1)

2009

the subjects or characters in imagined scenes. In addition to toys brought from home, children animated classroom toys in their princess family minidramas; favorites included dolls and dollhouse toys, especially the "princess" (a Barbie's-little-sister-type doll in a long red and pink gown). Children animated dolls by moving them and speaking for them, keying their activity as pretense by changing the pitch of their voices and looking directly at the object while speaking (Sawyer, 1997).

\section{Anticipated identities in princess dolls}

The girls' play with Disney Princess dolls and texts was situated in gendered discourse within an activity system of global consumerism. As consumers, children participate in worldwide networks of distribution and consumption through multiple activities with Disney Princess products: purchasing licensed merchandise, displaying favorite dolls and clothing, or viewing television and video. To understand the identity messages that circulate through Disney Princess media, it is necessary to situate the brand in the relationship between the Disney Corporation and child consumers.

The Disney Princess films comprise five of the six top revenue-generating Disney films of all time. The most recent films debuted with blockbuster openings bundled with fast-food chain promotions and widely televised movie trailers. Following each film's release—or rerelease from the Disney vault — children are able to watch the video again and again on DVD, logging hours of at-home and on-demand viewing. These marketing strategies build breadth and depth in the market, creating widespread and long-lasting demand for Disney Princess films and related products. Opportunities for girls to identify with characters in the films through repeated viewings ensure that the princess dolls and sidekick action figures come prepackaged with familiar storylines that millions of children know by heart. 
Reading Research Quarterly, 44(1)

2009

The dolls' material designs are designed to appeal to children and to communicate a clear princess identity for play. Disney Princess Barbies adhere to a common set of feminine beauty norms, regardless of their individual ethnicity: hourglass-shaped body, glossy hair, long-lashed eyes, and heart-shaped face; hair color and style are emphasized as the primary distinguishing feature. From their glitter-encrusted plastic tiaras to the hems of their iconic color-coded satin gowns, they are swathed in a seductive aura of wealth, sweetness, and glamour (Pocahontas Barbie, barefoot and dressed in buckskin, is the exception as it communicates a child-of-nature, romanticized waif identity; Giroux, 1999, p. 157). Although Disney Princess fabric-stuffed dolls rely on the same identity color scheme, they send a different message. These dolls have soft fleece skin and yarn hair, materials associated with infant toys that invite cuddling. The colors of the yarn hair, shimmery fabric gowns, and ballet slippers on the fabric dolls make up recognizable signs in a color scheme that symbolize the eight Disney Princess characters (see Table 1).

\section{Discourse of emphasized femininity}

...one important cultural and ideological reading of the narratives of the toy industry shows the construction and repetition of a "hegemonic masculinity" and its corollary: "emphasized femininity." Two separate, opposite gender roles are created and maintained through such images and narratives of Superman and Barbie which, by being separate and markedly different, work eventually to hold a hierarchy of male power in place. (Hilton, 1996, p. 35)

Emphasized femininity is a subordinate discourse to hegemonic masculinity (Connell, 1987) that stresses gender differences and legitimates the construction of girls as objects of display and boys as subjects with power (Butler, 1993). These gender expectations are repeated across all the Disney films, even in the films with more independent heroines: Belle fends off a macho suitor 
Reading Research Quarterly, 44(1)

2009

with her passion for reading but eventually falls for the Beast and becomes mistress of the castle and its singing houseware; Ariel, an inquisitive mermaid who defies a domineering father, becomes demure and silent on land in her prince's world (LaCroix, 2004). A recurrent device in recent Disney Princess films is tension around the princess character's decision (requirement) to marry: She often prefers a bad-boy suitor over her father's choice for her husband (Do Rozario, 2004). Regardless of her choice, the princess upholds male patriarchy by serving as the key to the kingdom to be earned by an active, deserving hero. In this way, emphasized femininity operating through beauty ideals objectifies the princess as the prize.

The rigid gender roles in The Little Mermaid are not isolated instances in Disney's filmic universe; on the contrary, Disney's negative stereotypes about women and girls gain force through the way in which similar messages are circulated and reproduced, in varying degrees, in many of Disney's animated films. (Giroux, 1999, p. 100)

The creation of the Disney Princess brand further amplifies the discourse of emphasized femininity by bringing together the eight heroines, homogenizing them by highlighting their common beauty ideal and washing out their slight variations in personality and power to control their own destinies. It is a highly effective marketing strategy; millions of young consumers continue to purchase the dolls and play the accompanying princess identity texts, demonstrated by the unflagging global popularity of the nine-year-old brand (Disney Consumer Products, 2007).

\section{Consuming anticipated identities}

The Disney Princess Players enthusiastically took up and animated the personas of Disney Princess characters as they brought their own dolls and toys to school. Zoe almost always toted at least one doll in her backpack; the variety was impressive, including vinyl Barbie-style fashion 
Reading Research Quarterly, 44(1)

2009

dolls and soft rag-doll versions. The children's shared recognition of the princesses' symbolic colors and familiar storylines enabled more stability and durability of meanings so that little setup was needed to get play started and fewer interruptions were needed to talk about the next play move.

Play offered the opportunity to alter the character identity that comes prepackaged with commercial dolls and to reattach a play-inspired identity. New identities could be assigned to dolls by explicitly stating the altered relationship during play negotiations that occurred outside the play scenario.

Zoe pulls two fabric dolls out of her backpack and hands Clare a brown-haired doll in a yellow dress, telling her "You be Belle; I'm Sleeping Beauty," referring to the blonde doll in a pink dress. The girls dance the dolls around the edge of the table. Zoe tells Clare, "They're sisters; this one got adopted," pointing to her own doll. Peter approaches the girls, clutching the small redgowned doll that is part of the classroom dollhouse collection. He suggests, "And I was the little sister of you both.” Zoe cuts him off, "No.” Peter pauses and tries another tack, "Can I hold her?" reaching for Clare's doll. She hands over Belle and Peter hands her the little doll in exchange. (field notes, February 22, 2006)

Identity-text transformations depended upon recognition of the proposed change by other players in the group. Zoe's suggestion that the dolls be sisters was immediately accepted by Clare. The suggestion that the princess dolls be sisters was easily incorporated into the girls' play. Zoe deftly detached Sleeping Beauty from her family and reestablished a new relationship, smoothing over Clare's potential objections with the adoption ploy. Finding or creating a "good family" is consistent with the goals of emphasized femininity discourse (Walkerdine, 1984) and a goal in the abused stepdaughter to princess-bride storylines in Cinderella and Snow White. 
Reading Research Quarterly, 44(1)

2009

However, Peter's proposition to join the girls' play was quickly rejected even though he had played princess stories with Zoe, Clare, and Mei Yu on other occasions. His suggestion to add a little sister used several strategies necessary for successful entry bids in children's play groups (Corsaro, 2003): He offered a specific role for his character rather than a general "Can I play?" request; the proposal to add another sibling fits the girls' established family-play scenario; he also had the appropriate cultural capital as an experienced player with a favorite classroom doll valued by the affinity group.

The possible reasons for Zoe's rejection can be examined as layers sedimented through the children's play histories with the toys: Her reasons could be social—-to exclude this particular child from her play group, material — to reject the doll as not officially or credibly a Disney Princess, meaning-based - to reject the addition of another character in the co-constructed play scenario, and/or discursive — to enforce and maintain gender boundaries for doll play. Emphasized femininity discourse, amplified through the dolls' material features and media storylines, constructs boys as inappropriate players for the hyper-feminine dolls. Although Zoe was happy to include Nicholas and Peter in princess play themes with the generic classroom dolls, she excluded both of them from play with the commercial Disney Princess dolls. Regardless of her reasons, Zoe clearly wielded power over Peter by rejecting his entry bid into play. Clare restored Peter's status and included him in the play group by trading dolls with him. By the end of the year, the potential to exercise power during play was increased when Abbie encouraged the children to write and produce their own plays, which allowed child directors to assign character identities to actors and to animate their peers rather than animating dolls. 


\section{Authoring Books, Plays, and Identities in Writing Workshop}

\section{Key practice: Approximated writing}

During writing workshop or choice time, children initiated their own writing projects as they wrote, illustrated, and designed print and images for journals, letters and cards to friends, pages for child-produced books, storyboards, and puppet plays. Approximated writing represents the range of ways in which children can negotiate the tension between their personally invented forms and culturally determined conventions for language (Goodman, 1994. In Abbie's classroom, children used approximated writing to craft meaningful messages by applying their emerging understanding of syntactic and grapho-phonic systems and drawing upon available resources: their personal literacy histories (Whitmore \& Goodman, 1995), knowledgeable others, or visual models in the classroom. Disney Princess Players engaged in approximated writing in $36 \%$ of all coded events. For example, Mei Yu used approximated writing to write a script for her puppet play (see Figure 1). She coordinated her intended meaning with grapho-phonic conventions (e.g., using the alphabetic symbols "tuc" to represent sounds in the word took or remembering the visual configuration of the words into and the, attempting to meet the need for at least one vowel in each word) and punctuation (e.g., spacing between words and arranging words in horizontal lines; overgeneralizing the need for punctuation by placing marks at the end of each line; experimenting with exclamation points and page numbers; Kress, 1997; Martens, 1996; Owocki \& Goodman, 2002).

\section{Key practice: Authoring}

Disney Princess Players' writing practices reflected not only how children approximated conventions to get words on the page but also why they wrote. Authoring occurred when children told, wrote, drew, and/or dramatized connected texts for child-made books that they read from the author's chair or plays that they performed for the class to watch and which Abbie 
Reading Research Quarterly, 44(1)

2009

videotaped (children also used iMovie to edit their films with the assistance of parent volunteers and the library media specialist, but these activities were not videotaped nor analyzed as they involved adult-directed activity that occurred outside the classroom). Disney Princess Players engaged in authoring more frequently than other groups did (42\% of coded activity).

Authoring included several subpractices that supported children's production of written texts with appropriate genre features: illustrating, developing characters, organizing plot, and adding dialogue. Children wrote scripts with narrative and dialogue for plays and puppet shows but also sketched storyboards to plan out each scene. The left-to-right progression of scenes in storyboard panels stressed the linearity of narrative, drawing children's attention to action sequences and moving them beyond initial static displays (e.g., “This is a....”). For example, Mei Yu's storyboard planned an action sequence for four characters in her puppet show: a princess, a queen, and two kings. The king and queen were centered in each scene, facing forward, arms at their sides, static displays that show family relationships rather than action. Mei Yu added action by interspersing the character frames with drawings of stairs to show movement between rooms of the castle and by adding props and dialogue to the family display scenes.

\section{Sedimenting writing practices and author identities}

As a child-centered literacy activity, writing workshop positions children as capable writers who actively cocreate meaning (Calkins, 1986; Graves, 1983) and encourages collaborative talk to develop their literacy proficiency (Barnes \& Todd, 1995). In writing workshop's progressivist pedagogy, children are encouraged to explore genres of written communication and freely express ideas through their writing and conversations about literature (Newkirk, 1989; Newkirk \& McClure, 1992; Ray, 2004). The sedimented writing practices in books "authorized" children by providing a product that served as concrete evidence of authorship, a material artifact with cultural capital in this community of emergent writers. Children knew without asking that a 
Reading Research Quarterly, 44(1)

2009

freshly illustrated book placed on the big wooden rocker would generate a chance to sit in the author's chair, to read the book to the class, and to be admired and questioned at the close of writing workshop.

\section{Discourse of creative expression}

The discourse of creative expression (Ivanič, 2004) is circulated through the activity system of writing workshop, encouraging learner agency and free expression through a set of routine practices that solicits children's ideas, encourages talk among peers, empowers autonomy in writing decisions during teacher writing conferences, and explicitly refers to children as authors (Newkirk, 2007; Wohlwend, in press). This is not to imply that discourse is the same as lived experience; numerous studies have shown that children's writing in school can hardly be called free expression as it is monitored and constrained by teacher and peer sanctions (Finders, 1997; Kamler, 1994; Lensmire, 1994). However, in Abbie's classroom, children exercised a remarkable degree of autonomy. At the beginning of each writing workshop, children told Abbie what they would be working on, not the other way around. During workshop, children abandoned projects on their own (without asking for teacher permission, which would have been superfluous), consulted with other children if they wanted opinions or help, and declined or ignored Abbie's proffered suggestions toward revision when they thought their original idea was better.

\section{Producing anticipated identities}

Although children readily negotiated over story meanings as players, they adhered more closely to their own interpretations of familiar storylines when writing books. The emphasis on individual creative expression in writing workshop encouraged some talk among children, but not the intensely collaborative talk necessary to sustain shared meanings during dramatic play. 
Reading Research Quarterly, 44(1)

2009

Rather, children wrote individually, stopping occasionally to glance at and comment on a neighboring child's writing.

As Zoe illustrates a page for her Mulan book, Peter watches. After a few minutes, he asks, "How about the three princesses?"

Without looking up, Zoe replies, "There aren't three princesses."

"In Mulan 2! She has three friends and they are the three princesses."

Zoe dismisses his suggestion and announces with finality, "I only know Mulan." Turning to the last page in her blank book, she quickly sketches out a wedding scene. (video data, January 18, 2006)

As Zoe and Peter demonstrated on this and several other occasions, debates arose over what constituted "real" stories, as children drew distinctions between the original films and the proliferation of Disney-produced direct-to-video sequels and television program spin-offs. Disney Princess Players' discussions about their writings and drawings displayed their mastery of princess-film repertoire. Children frequently talked while writing to advise each other and to impose their individual recollections and interpretations of the familiar princess storylines. When children actually played their written texts, however, they were more apt to face the need to improvise and later rethink, revisit, and revise their stories; that is, the nexus of play and writing practices prompted transformation of played identities and written texts.

\section{Transforming Identities and Texts in the Playing/Writing Nexus}

\section{The playing/writing nexus: Playing to write and writing to play}

Nexus are intersections where practices link and strengthen each other; in the playing/writing nexus, children's play enhances their writing and their writing enhances their play. Animating 
Reading Research Quarterly, 44(1)

2009

prompts authors to add more action and dialogue for characters in scripts and storyboards and more detailed illustrations in books. Mei Yu's play practices developed her writing when, after running through impromptu rehearsals with her stick puppets at the writing table, she added the script in Figure 1 and created a castle backdrop and related props, such as paper cocoa mugs taped to popsicle sticks. Similarly, Mei Yu's writing practices supported her play goals when she read her script, giving meaning to her bouncing hand motions as she manipulated stick puppets.

However, nexus of writing and playing practices often did not occur in the same time and space. Instead, children used toys and their writing artifacts to stabilize meanings and connect story events across a period of days. Dolls and storyboards allowed children to link playing/writing practices and access the sedimented meanings and identities that they had previously negotiated with other players or writers.

\section{Linking playing and writing practices through dolls and storyboards}

Dolls and storyboards linked authoring events during writing workshop with animating events during child-directed play scenarios. Toys and children's writings held sedimented meanings of commercially produced, well-known Disney storylines as well as the story innovations that children coconstructed during play. Chains of animating and authoring events created and contained transformations of identities and meanings. Toys and writings produced and/or played within these events acted as meaning carriers that allowed children to pick up where they left off as they returned to a project at subsequent times or in different spaces. For example, a child could animate a princess doll one day and on the next day, find the doll and prop it on the table while recalling the story and drawing a storyboard.

Storyboards provided a crucial link that connected children's writings to their performances and stabilized story meanings to be played later. Children used storyboards as functional tools rather than displays, focusing on their usefulness in planning a performance. Zoe 
Reading Research Quarterly, 44(1)

2009

sketched out her panels with a cartoonist's speed, allowing stick figures and minimal drawings to communicate the action. She ruthlessly crossed out and wrote over her drawings to correct them. Her quick drawing could easily be criticized in some classrooms as rushing to be finished or carelessness rather than appreciated as skillful drafting or as evidence that she sees writing as a process.

\section{Improvisation and revision in an animating/authoring chain}

A chain of writing and play events eventually led to a revision in a book Zoe wrote about Sleeping Beauty. In the first event, Zoe used approximated writing to spell and carefully letter the title "SEPN BUDE" on the front cover of her book, adding curling serifs to the letters of the title to simulate Disney Princess commercial fonts. In the second event, the princess-sisters play episode described earlier, Zoe and Clare transformed the Aurora and Belle fabric dolls into sisters and Peter offered his improvised suggestion that his doll join the family as a little sister. Although Zoe rejected Peter's improvisation of a little sister for two princess sisters, she revisited the idea in the third event in the chain when she returned to her book during writer's workshop. After drawing a weeping queen and a crumpling princess after Princess Aurora's encounter with a poisoned spinning wheel, Zoe incorporated Peter's improvisation and introduced a new character: Aurora's baby sister appeared in the bottom right corner of the page, crawling toward the action (see Figure 2).

\section{Transforming Sleeping Beauty in the playing/writing nexus}

A much denser chain of transformative events occurred during children's playwriting. To produce a play based upon Sleeping Beauty, Zoe linked authoring events that enhanced animation (i.e., writing storyboards, creating cast lists of characters) with animating events that enhanced her written texts (i.e., clarifying character roles, inventing dialogue, and organizing the plot sequence while performing the play). During the play, Zoe created and repeatedly revised a 
Reading Research Quarterly, 44(1)

2009

four-panel storyboard with 14 scenes (teacher interview, digital photographs, April 19, 2006).

This authoring/animating chain prompted multiple revisions and improvised transformations of the original fairy tale and Zoe's planned text by Zoe and by other members of the cast. The following description of the play's videotaped production presents an overview of the total action in the play.

\section{Performing Sleeping Beauty}

Zoe, Mei Yu, Clare, Colin, Marshall, Matt, and Emma sit in the hallway just outside the kindergarten room, ready to begin Zoe's version of Sleeping Beauty. I have volunteered to do the videotaping for the final version of the play that Zoe has written and is directing. Zoe and the cast move outdoors to the playground where she directs the actors by shouting out their actions and dialogue. Zoe periodically checks her storyboard for the next direction, occasionally jumbling her planned sequence of scenes.

1. Scene 1, outside the castle: Zoe is playing Princess Aurora and Emma is playing the Maleficent, the Disney villain. Zoe shouts, "You're chasing me," and Emma promptly runs after her in a small circle on the grassy area of the playground. Zoe yells, "Cut!"

2. Scene 2, the castle tower (bicycle rack): Zoe runs and stands next to the bicycle rack that represents the castle tower. She shouts to the prince, "Colin! Colin! You're climbing up my hair." She first tilts her head, Rapunzel fashion, to let her hair hang over the metal bars. Then in her animator role as director, Zoe crouches down and pantomimes climbing hand over hand, demonstrating how Colin should climb up the bicycle rack pole.

3. Scene 3, outside the castle (next to the bicycle rack): Zoe reads her storyboard, "The next scene is...OK! Colin, Colin, Matt, and that's all." Matt, playing the dragon, follows Zoe's direction to breathe smoke at her. Colin is confused about his next line and Teresa 
(an actor who is watching off-camera) tries to prompt him but Zoe rejects her help as interference. Zoe insists that Colin say "Get away!" and when he does, Zoe runs away from him across the playground.

4. Replay of Scene 1: “OK! Emma, chase me again!” Zoe runs back onto the grass with Emma in pursuit. "Cut!"

The play continues with scenes in which the three fairies cook dinner in their cottage and the king and queen cook dinner in their castle. When Zoe directs Maleficent to cast a sleeping spell that stupefies Princess Aurora by saying, "Emma, come put a magic spell on me," Emma taps Zoe lightly on the top of her head, and Zoe sinks to the ground and lies rigidly on the grass. As an afterthought, she folds her hands across her chest. Suddenly, she sits up, runs off camera to consult her storyboard and then returns to her prone position. Lifting just her head off the ground, she calls out directions to the prince who obediently runs over and revives her with a hug. These quieter scenes are interspersed with frenetic chase scenes and fencing duels in which the princess/director grabs the sword away from the prince to demonstrate the proper way to jab at a fleeing dragon. When the dragon is finally cornered, Princess Aurora tucks one hand in the prince's arm and with the other accepts a bouquet of oozing dandelions spontaneously gathered off camera during the chase scenes by Maleficent and the good fairies. As the couple walks slowly down the sidewalk, Zoe directs the wedding guests to compliment her, "You say, 'What a beautiful dress you have on."” (video data, April 20, 2006)

At each step in the process from storyboard to video production of the Sleeping Beauty play, Zoe wavered between faithful replication of a movie that she loved with its beautiful, archetypically passive princess and creative innovation that offered more active and satisfying 
Reading Research Quarterly, 44(1)

2009

feats for her own character. In these improvised transformations, she chased down the dragon while shouting "Surrendah!" and jabbing at the retreating actor with a cardboard sword.

\section{Revising the storyboard for Sleeping Beauty}

Visual analysis of Zoe's storyboard, shown in Figures 3 through 6, reveals transformations of the Disney film plot. Repeated revisions removed Scenes 5 and 6 (top half of Figure 4), added a wedding scene at the end (Figure 6), furnished explanatory print (e.g., "The Sleep" in Scene 8 in bottom right corner of Figure 4) and stage directions (e.g., "They hug" in Scene 11 in bottom left corner of Figure 5), and provided actors with interesting dialogue (e.g., "Rock on!" in Scene 10 in the top right corner in Figure 5), including a cryptic sequence between an imprisoned Princess Aurora and the villain Maleficent: "Why?" "Because" (Scene 2 in top right corner of Figure 3). She added long hair to one of the characters, changing a dueling prince into a dueling princess. Zoe's struggle with the passivity of the princess in the Disney text is apparent through social semiotic visual analysis (Jewitt \& Oyama, 2001; Kress \& van Leeuwen, 1996) of her storyboard revisions. Except for the final frame with a wedding portrait, Zoe's storyboard is filled with narrative representations that show characters doing something rather than conceptual representations of static displays that show characters being someone. In visual analysis, narrative representations are identified by the presence of vectors, lines — frequently diagonalthat flow between principals and indicate action. In Zoe's initial drawing of the prince and princess in Scene 11 (bottom left frame in storyboard panel in Figure 5), the vector of a single diagonal lip line that connects the two figures' mouths represents a kiss. Vectors are dynamic, indicating that something is happening. Further, vectors are bidirectional so the point of origin must be determined by other information on the page. Of course, the Sleeping Beauty storyline explicitly provides this information: The prince is doing the kissing. In fact, the entire fairy tale revolves around the central theme of prince as heroic rescuer and princess as comatose victim, 
but the point here is that multiple graphic elements of Zoe's drawing cumulatively stress this active/passive relationship. The placement of the prince's head above the princess' head, combined with the diagonal vector of the kiss, which signals motion, visually communicates that the prince is the originator of the action, and the princess is the recipient. The active/passive relationship is expressed in two ways: vertical/horizontal and armed/armless. The primarily vertical orientation of two vectors that are the prince's arms juxtaposed against the horizontal orientation of the armless princess reiterates that he is active and she is passive. In her first revision, Zoe labels this scene "CICC" [kiss]. In the following revision to the panel, she crosses out the word CICC and pencils in arms for the princess, which changes the kiss to a hug and makes her character slightly more active through the addition of two princess-originated vectors. She scribbles over the kissing faces and writes "teey Hude" [They hug]. This revision from kiss to hug, which is probably more acceptable in both peer and school cultures, is played out in the rehearsed version and the final videotaped version of her play. Important to the notion of sedimented identities, Zoe continued to revise her storyboard to reflect changes to the plot even after the final videotaping.

\section{Improvising and constraining character actions in Sleeping Beauty}

Plays were particularly rich transformative events that created tiered performances and relationships, allowing animators to animate characters indirectly through actors who enacted their characters directly. As an author, Zoe could revise her text to reflect her personal interpretation of the film. As an actor playing a princess, Zoe could interact with the other actors but in ways bounded by her own preplanned text. As an animator, Zoe could cast and recast actors' roles and critique and enforce her expectations for their performances. In contrast to doll play where animators controlled inanimate objects, plays provided opportunities for actors to challenge the animator's direction. Table 2 lists the scenes and the improvisations and revisions 
Reading Research Quarterly, 44(1)

2009

that occurred in a chain packed with transformations, from the creation of the storyboard to the rehearsal, videotaping, and final revision that Zoe made after filming was finished. For example, Zoe repeatedly reworked Scene 7. At the rehearsal, she first switched the action and characters from a sword fight between Maleficent and the prince to a chase scene in which the prince was to jab and chase a fleeing dragon. After the dragon chase resulted in the two actors running wildly in circles, Zoe made some revisions to her storyboard. She added dialogue to the scene and made a sword prop for the prince by taping a paper triangle to a cardboard wrapping paper tube. These revisions successfully provided more structure for the scene when it was replayed the next day for the final performance. However, Zoe was not satisfied with the prince's fencing style of wagging the sword at the dragon. Zoe rushed into the action, calling out, "Do it like this, Colin!" Taking the sword from him, she held it out stiffly and alternately lunged and galloped after the dragon until she backed him against a wall. Finally, even though videotaping was finished, Zoe recorded a final change on her storyboard by adding long hair to the prince's head and changing the prince to a princess (Scene 7 in Figure 4). This transformation dramatically illustrated Zoe's ability to direct and to rewrite the role of helpless victim.

Empowering transformations occurred in other scenes across the chain but in more subtle ways. In the previous section, close visual analysis of Zoe's storyboard revealed several text revisions that correspond to play improvisations that are only visible through microanalysis of the video data. For example, the children's enactment of Scene 3 was confused and chaotic in live action: The dragon puffed smoke at the princess, the prince said "Get away" to the princess, and she ran away from both of them. However, microanalysis of the action in Scene 3 in Table 3 shows Colin's challenge to Zoe's text and her struggle to maintain the integrity of her storyboard plan and her authority as director. The transcript reveals Zoe's improvised solution that 
Reading Research Quarterly, 44(1)

2009

preserved the meaning of her original text and maintained a more powerful role for her princess character. Scene 3 began with the dragon (Matt) breathing smoke at Princess Aurora (Zoe) and the prince (Colin) standing off to the side. Zoe fended off Colin's bid to improvise and add a character so that he could play a second fire-breathing dragon (Turn 5). Instead, she insisted that he stick to the storyboard plan and play the prince (Turn 6). In Turn 7, Colin misinterpreted Zoe's direction and threatened the dragon, saying "Get away" (with a look and body posture that implied “or else"). In Turns 8 and 9, Colin was nonplussed by Zoe’s correction of his performance and her insistence that the prince warn the princess to "get away" (to flee the dragon).

The dual meanings of the text "Get away!" imply opposing contexts: In the first context, the prince shouts at and actively fights off the dragon; in the second, the prince passively stands by and shouts out a warning to the princess. Colin, a talented and inventive actor with a gift for creating startlingly realistic dialogue, could not envision the passive role for the prince that Zoe intended. Zoe clearly depicted this passivity in Scene 3 on her storyboard (see Figure 3). In this frame, the dragon blows steam on a screaming princess while the prince walks away holding sword and shield, his head down and back turned to the action.

The play stalled as Colin tried to puzzle out a sensible move for the prince. Encouragement by Theresa to say "Get away!" did not clarify the meaning conflict for him. Frustrated, Zoe verbally and physically rejected Theresa's intervention as an unwarranted intrusion. This prompted a visiting preservice teacher to step in and try to help by also directing Colin to say "Get away!" The adult intervention prevented the possibility of further talk between the children that might have allowed them to see the contradiction between the two implied contexts. Colin abandoned the attempt to make sense of the scene and advanced menacingly 
Reading Research Quarterly, 44(1)

2009

toward Zoe, arms raised and fingers crooked as if ready to attack. At this point, Zoe also gave up on making sense with Colin and simply ran away from him.

Further conversation between author and actor might have allowed the children to sort out text meanings and negotiate character roles. Despite the prevalence of collaborative talk about shared meanings during improvised play scenarios at the dollhouse, the players did not talk out their conflicting interpretations during this performance. Instead, Colin accepted a nonsensical script, and Zoe accepted a nonsensical performance. Perhaps Colin felt constrained by an actor's responsibility to follow the author/animator's direction and text when enacting someone else's authored play, perhaps the children recognized that this videotaping was a final performance so discussion of the scene would not be in keeping with a polished run-through, or perhaps they felt that any attempt to further discuss the scene would disobey the teacher associate's implicit direction to get on with the performance. Fortunately, Zoe quickly improvised a way to restore the meaning of her original text by replaying Scene 1 with Emma (see Turns 16 and 17 in Table 3). The replaying of the chase scene reestablishes Maleficent (Emma's character) as the primary threat to the princess and glosses over Colin's misplayed line as an attacking prince. At several points in the play, similar impromptu transformations by Zoe created a way to keep the play moving forward while maintaining the meaning of both her storyboard and the original film.

For authors/animators in Abbie's classroom, plays offered dual opportunities to animate fantasy characters and to direct other children from an authorized leadership position. Zoe, energized by this empowered position, ran around at an almost manic pace during the filming. In contrast, the other actors acted stiffly and stood passively to the side. At first, I was surprised that children who were so lively and inventive during enactments in the housekeeping center were so 
Reading Research Quarterly, 44(1)

2009

silent during child-written plays, pantomiming their actions and rarely speaking outside the play

frame. As demonstrated by Zoe's and Colin's restricted innovation and miscommunication in

Scene 3, I realized that although the children could improvise and collaborate during their own

enactments, they were constrained by authorial expectations when enacting someone else's

script.

\section{Transforming a Disney Princess doll}

Through the remainder of the school year, Zoe continued to write about and play with the princess dolls she loved but with stronger and more active identities. By the end of the school year, Zoe had transformed Mulan from a Disney Princess to a superhero, improvising an outfit with a short skirt and cape appropriated from her Barbie's wardrobe. Zoe described her doll as follows:

She's really a princess, but I'm pretending she's a superhero. Her powers make her fly. She can make tornadoes. She can use power from her hands to make fire. Sometimes she makes the bad guy dead with her fire. This is how they make her weak: They make a stronger power-windand they blow her over to the door. My mom got her for me when I got back home from Disney World. That's not her natural clothes; her natural clothes — but I got this - this is my other Barbie's thing — this is her-my Barbie's cheerleading skirt... I want her to talk in there. [Lowering pitch of her voice and bending close to the digital voice recorder.] I have superpowers and I am a superhero and I can't have a lot of powers and I can make tornadoes. (audio data, May 18, 2006)

In revising Mulan, Zoe sedimented her history of practices and identities as she changed the doll's texts. Zoe's continuing struggle with the tension between active animator and feminine passivity was evident in her transformation of a princess into a strong, but still not too powerful, 
Reading Research Quarterly, 44(1)

2009

superhero who “can't have a lot of powers." To replace princess Mulan's "natural clothes” (a traditional silk robe that came with the doll), Zoe appropriated clothes from her "other Barbie's" wardrobe: a short "cheerleading skirt" and a long red jacket. The design of this invented outfit simulated a comic book hero's tight-fitting uniform and cape, which Zoe made more credible when she animated Super-Mulan by holding the doll horizontally and flying it around the classroom. During a follow-up interview, her mother verified Zoe's interest in superheroes and comics, noting that Zoe read "boy comics and all kinds of comics," "loved Star Wars," and wrote about superheroes in addition to playing with Disney Princess dolls at home. Mulan, one of Zoe's favorite dolls, had been given to Zoe by her mother who grew up in China and encouraged Zoe to value Chinese language, writing, and cultural traditions (a manuscript in preparation provides a more thorough discussion of the ways Zoe and her mother negotiated the tensions between Disney's portrayals of dragons and Chinese culture as well as other crosscultural differences between school discourses and Chinese cultural values, such as respect for teachers, working rather than playing at school, learning Chinese languages, and learning to write Chinese characters correctly). Revising the doll's princess text to superhero allowed Zoe to animate a more powerful proxy, to fight the bad guy with her bare hands, and to make tornadoes. The addition of a tornado-making superpower resonated with a prominent theme in the housekeeping corner (children played out their personal experiences with a violent tornado that had happened in the community that spring). Peeling away the sedimented identities layered in this revised toy text reveal Zoe as an active author and animator, as a fashion doll consumer, as a comic book superhero fan, as the daughter of a Chinese mother, and as a tornado survivor.

Zoe's revision of the doll's identity text in the Mulan book stood in sharp contrast to the identity-text revision in the Sleeping Beauty play she wrote months later. Although the Disney 
storyline (and of course, the historical text) already enabled a warrior role for Mulan, Zoe did not draw or write about battles in the book. Rather, Zoe's Mulan book contained a collection of static displays that looked more like a family or wedding album than a narrative with an active heroine.

\section{Discussion: Productive Consumption in the Playing/Writing Nexus}

\section{Improvising and Revising Gendered Identity Texts}

In the playing/writing nexus, animation breathed life into a toy or got an actor moving, transforming static images into realized action as proxies played out scenes from Mei Yu's or Zoe's storyboards. The practice of animating a toy projected an identity onto a proxy and brought an inanimate object into the world of action. The storylines of princess dolls were well known to multiple players and readily available with minimal explanation, enabling the dolls' quick pivots from the here-and-now to fantasy scenarios. Dolls, action figures, and stuffed animals are particularly meaning-laden texts that invite identity transformation as children animate the materials and project play identities through them.

The practice of authoring in the playing/writing nexus created a text and character identities while transforming the child into author and director. As Disney Princess Players wrote narratives in books, drew storyboard images, and voiced scripts, their focus on meaning-making contrasted sharply with the repetitive labeling of static images (e.g., "This is..." or "I like...") that was more typical of children's writing in other kindergarten classrooms I observed. Chains that linked nexus were recursively expansive as the prospect of playing a story prompted children to add dialogue and attend to logical sequences of action; richer depiction in writing followed the discoveries and expanded meanings afforded by transmediating text to drama (Siegel, 1995, 2006). 
Play expands opportunities for transformation by recontextualizing classroom activity into "... play frames [that] not only alter the performative force of utterances but provide settings in which speech and society can be questioned and transformed" (Bauman \& Briggs, 1990, p. 63). Meaning shifts occur as the here-and-now meanings of objects are detached and resituated in a new context through pretense. Recontextualization of language, actions, and materials in the immediate situation indexed and imagined other meanings in more distant events. Play laminated time-spaces (Leander, 2002a), aggregating sedimented identities from play spaces and the classroom space and multiplying opportunities for invoking empowered roles that could socially position other players In the playing/writing nexus, dolls' indexed storylines and anticipated identities layered into children's written texts, and the authoring identities sedimented onto storyboards. Each playing or writing event layered additional meanings and identities onto prior shared meanings and identities sedimented through previous play negotiations and enactments. In this way, toys and storyboards accessed distant time-spaces, laminating not only the immediate real and pretended contexts but also prior play events. Dolls and storyboards offered concrete repositories that carried and stabilized story meanings and were paradoxically packed with potential for transformation. As children selected from the universe of possible identities and contexts for pretense, they took up disparately empowered subject positions within discourses of emphasized femininity and creative expression. Because these identities were relational (e.g., princess/prince, actor/director, character/author, boy/girl), play laminations allowed children to access and exert power over peers that might not be otherwise available in classroom reality.

Play transformations have durable effects beyond temporary play scenarios. Children's social standing was affected not only by their play relationships but by the identities that they 
Reading Research Quarterly, 44(1)

2009

sedimented into toys, producing objects that were prized in peer culture. When an affinity group valued a particular object, they transformed an ordinary toy, book, or storyboard into objectified forms of cultural capital. These objects transmitted status and acted as social markers among children in the peer culture (Elgas, Klein, Kantor, \& Fernie, 1988) and as potential conduits for disrupting power relations (Foucault, 1978). Power to direct play scenarios was influenced by who held possession of the most valued toys: As owner with the power to distribute the dolls, Zoe was able to establish herself as the leader of play with the right to exclude Peter; by trading dolls with Peter, Clare opened up access and included him in the play group.

The storyboard emerged in authoring/animating chains as a key artifact that concretized not only the authorized text but also a child's authority to direct. Disney Princess Players positioned actors through physical gestures, acting directions, and references to child-authored storyboards or to familiar plots from the commercial films with cultural models ("someday my prince will come") and situated identities (e.g., helpless/hapless ingénue as problem, rescuing prince as solution) associated with their gendered storylines (Giroux, 1997, 1999 Walkerdine, 1984). The storyboard legitimated author/animator decisions about character actions, restricted improvisations, and influenced the level and quality of a child's participation. Storyboards allowed authors/animators to assign roles, to control the text and the performances, and to sanction and limit transformations.

However, neither the texts represented by the storyboard images nor the performances were finalized (Bakhtin, 1981). Dialogue, scenes, and character roles were always subject to revision but only as allowed by the author/animator as storyboards enabled only those revisions, improvisations, and performances that upheld the author's current interpretation of the text. As director, Zoe held the power to improvise: She replayed a scene to reestablish her intended 
Reading Research Quarterly, 44(1)

2009

meaning when Colin misinterpreted her direction to say "Get away!"; she stepped in as a fourth fairy to lead the scene from within the play frame; and she seized the sword to fight off the dragon herself. Animation inspired improvisation while authoring encouraged revision through a cycle of critique and improvisation. Repeatedly playing the damsel in distress allowed Zoe to experience dissatisfaction as a passive victim and to improvise a more empowered alternative role: After rehearsing and revising the play several times, Zoe first modeled the proper fencing style as director but then decided to keep the sword and fight the dragon herself. Her final revision, drawing long hair on the dueling prince, cemented the transformation of hero to heroine, from prince to princess.

\section{Girls, Discourses, and Productive Consumption}

This analysis suggests that time to explore and face the limitations of stereotypical gender roles and opportunities to act out alternatives are important. Critical literacy approaches that ask children to critique classic fairy tales or to accept new revisionist versions may reify gender norms in literacy practices by overly emphasizing gender differences (Millard, 2003). Play allows children to experience dissonance as they enact restrictive stereotypical roles and prompts children to improvise to overcome gendered obstacles that block more satisfying identity performances. When Zoe performed a princess identity, she experienced firsthand the social limitations of emphasized femininity that constrained her ability to defeat the evil fairy or battle a dragon. Zoe's agentic improvisations align with current research on young girls' play, literacy practices, and popular culture. Anne Haas Dyson's $(1997,2003)$ studies of writing workshop have shown that with teacher-supported opportunities to explore and appropriate popular culture in school, young girls can write their way into positions of more power by authoring roles for peers in classroom plays. Jackie Marsh (2006) found that when preschool girls played out the 
Reading Research Quarterly, 44(1)

2009

stories of Cinderella and Sleeping Beauty, the "media-related performances of children were not used simply to replicate stereotypical, hegemonic versions of gendered identities, although of course this was a predominant feature. At times, children resisted the normalisation process and presented contested and transgressive models of gendered practices...” (Marsh, 2005 p. 43). However, the subtle and seemingly chaotic transformations in Zoe's animating/authoring chain show that young girls may be writing and playing many transgressive texts that are only visible through close analysis of play interactions and texts.

It is important to recognize the variations in the ways that girls take up anticipated identities and discourses in toys. The Disney Princess Players' complicated relationships with the princess texts show that saturation of sedimented emphasized femininity identities in popularculture toys does not necessarily result in social reproduction of stereotypical roles. There was considerable variation among the girls' animations of dolls. Although all three girls used the dolls to play family themes in castle settings, Zoe engaged and stretched the princess role to accommodate her desire to take charge of her play and direct other actors. Further, boys as well as girls played princess identities and acted out the Disney storylines, although as the example with Peter, Clare, and Zoe showed, boys had a harder time gaining access to the girls' personal Disney Princess dolls. R.W. Connell has revisited the gender discourses that he identified 20 years ago and has warned against overly simplistic and deterministic interpretations of gender categories that tend to homogenize the lived diversity in gender relations:

The concept of emphasized femininity focused on compliance to patriarchy, and this is still highly relevant in contemporary mass culture...our understanding of hegemonic masculinity needs to incorporate a more holistic understanding of gender hierarchy, recognizing the agency of 
Reading Research Quarterly, 44(1)

2009

subordinated groups as much as the power of dominant groups and the mutual conditioning of gender dynamics and other social dynamics. (Connell \& Messerschmidt, 2005, p. 848)

Gender is a social construction that does not reflect the complexity of lived lives. Emphasis on gender differences can exacerbate inequitable literacy practices when girls are constructed as passive literacy learners who read and write about school-appropriate topics and boys are constructed as active learners who need special encouragement to engage in literacy (Nichols, 2002). Because of the "boy problem," teachers are urged to infuse their literacy curricula with popular-culture material and masculine topics: science fiction, superheroes, horror genres, and video games (Newkirk, 2002). Girls' interests are characterized as already aligning with school culture, implying that no special attention is needed to integrate or mediate popular-culture material that appeals to girls (Millard, 2003).

The meanings that young children produce through play tend to be characterized as fleeting, trivial, and innocent rather than durable, literate, and ideological. The play ethos, a powerful and educationally romantic rhetoric (Sutton-Smith, 1997) that operates in earlychildhood classrooms, regards play as necessary and all good for all children (Smith, 1988). However, when Mei Yu, Clare, and Zoe played with and wrote about Disney Princess dolls, they reproduced (and sometimes contested) pervasive gender stereotypes in commercial media and in toy manufacturer's expectations for typical toy users. Disney Princess dolls and texts provided opportunities to play anticipated identities associated with discourses of emphasized femininity that the girls found simultaneously appealing and confining. I argue that play is not only an undervalued symbol system of transformative practices but also a power-laden site that shapes children's texts, identities, and participation in classrooms. Opportunities to transform texts and exercise power increase when play combines with literacy. What made the playing/writing nexus 
Reading Research Quarterly, 44(1)

2009

so powerful is that in the recursive process of improvising actions for characters and revising a

text, Disney Princess Players were revising identity texts situated in discourses of gender, consumerism, and learning to write.

The Disney Princess Players were avid Disney Princess fans, but they were not passive consumers. Zoe transformed Princess Aurora from victim to self-rescuer. All three girls adapted princess dolls to play out family scenarios that fit into their own experiences, writing a script in which the king and queen go inside the castle to take a nap, turning a princess into an adopted daughter, or drawing weddings to end their books. Michel de Certeau's (1984) notion of productive consumption explains how play supported children's emulations and improvisations of Disney dolls and storylines. Productive consumption challenges the characterization of proliferating media as a unidirectional onslaught on consumers. According to de Certeau, viewing/reading a multimedia text is simultaneously an act of consumption and an act of production as consumers make sense of products and produce personal meanings and strategic uses. Important to this case, productive consumption resonates with notions of children's agentic appropriation in social semiotics (Hodge \& Kress, 1988; Kress, 2003b) and in transactional literacy theory that supports creative expression discourse and writing workshop in Abbie's classroom. In a transactional process similar to productive consumption, readers and authors take equally productive semiotic roles as readers actively construct personal meanings_-including surplus meanings unimagined by the author - through recursive transactions with a text (Goodman, 1994; Rosenblatt, 1978).

Play adds another layer to productive consumption when children transact with sedimented identities and meanings in toys. Objects represent but do not exclusively contain a symbolic meaning (Scollon, 2001b). If a desired toy is not at hand, children easily pretend with 
Reading Research Quarterly, 44(1)

2009

some other object and reassign the transferred meaning. Manufacturers like Disney can make an expected use for a doll more likely by making it more appealing to a wide audience (popular pastel colors, silky hair, glistening fabrics), but individuals still animate the characters according to their own purposes. When interpreted as productive consumption, such small distortions by consumers constitute microtactics (Foucault, 1978) of everyday creativity that sap the strength of institutions and generate new trajectories (de Certeau, 1984). The Disney Princess Players demonstrate that it is necessary to look closely to see the subtle transactions with identities and text in children's interaction with popular media. The scope of Zoe's productive consumption of a Disney Princess identity and ensuing meaning negotiations with other players was only visible through microanalysis of texts and practices.

Productive consumption is located in the tension between agency and subjection; children are neither cultural dupes at the mercy of global corporations nor cultural geniuses who shrewdly access and expertly manipulate vast networks of gendered multimedia for their own purposes. Although Zoe exercised more agency than the Sleeping Beauty storyline actually provided, she still maintained masculine/feminine hierarchical relationships by excluding Peter from doll play, by using princess dolls to write and play family-focused stories, and by culminating her books and plays with weddings for happily-ever-after endings. The global distribution of Disney Princess products means that millions of young girls engage with the same toys and anticipated identities in myriad ways, reproducing and exploring, perhaps even improvising and revising, identity texts that have been regarded as innocent play outside the school curriculum and of little interest to educators. 


\section{Limitations}

There are limitations to this study related to the research focus, technological restrictions in data collection, and the fluid nature of children's play. The funnel structure of this qualitative research was designed to filter data to find rich examples for close examination. For example, Abbie's classroom was unique rather than typical of the kindergarten classrooms that I visited. Because the classroom was unusually playful, it offered the most promising opportunity for examining children's combinations of literacy and play. By design, the focus grew narrower as data collection and analysis progressed. Stationing cameras within specific locations where more literacy play practices occurred meant that interesting activity in other locations was not captured. The focus on collective events in these locations meant that children who did not join one of the focal play groups were not typically recorded after the affinity groups were identified. Children moved freely around the classroom, in and out of play locations and the camera's view, so that it was necessary to rely on field notes to keep track of their interactions. As a result, transformations that happened elsewhere in the classroom after a child left the collective event location were not available for microanalysis. Due to these limitations, it is likely that nexus in this classroom were much denser, richer, and more complex than depicted here.

Similarly, ethnographic studies of children's literacy practices and doll play in other places, particularly at home, would enrich the findings and uncover further layers in the sedimented identities in children's family and community histories. Researchers who study parents' beliefs and participation in children's fascination with popular media have revealed that parents negotiate a complicated relationship between satisfying their children's desires, resisting stereotypes, and protecting childhood innocence (Marsh, 2005). Data collection in this study was limited to the classroom context; when I talked with parents, it was usually in informal, 
sometimes serendipitous, encounters at school. A more nuanced interpretation of families' expectations for children's schooling and gender performances requires a research focus that extends beyond the classroom to children's lived experiences in home and community. The nexus of play/writing juxtaposed not only Disney doll identity texts and schooling practices but also families' expectations for children's identity performances as girls and students. It is likely that Mei Yu, Zoe, and Clare experienced and negotiated layers of cross-cultural tensions as Chinese American or Filipino girls playing American versions of primarily white heroines in European fairy tales: The princess characters dress like European royalty and live in medieval castles; regardless of the their ethnicities or Old World trappings, Disney Princesses talk and act like middle-class American teenagers.

Finally, the playful approach to literacy in Abbie's classroom is situated in a U.S. school and promotes a particular Western, middle-class vision of child-centered learning. The global presence of Disney Princess toys suggests the need to critically study children's literacy practices with toys in international settings and across models of schooling.

\section{Implications: Making Room for Play and Popular Culture in Literacy}

\section{Classrooms}

Play nexus, whether playing/writing, playing/reading, or playing/designing, emerged in the larger study as facile sites for exploring and remodeling gendered identities as children wrote and directed Sleeping Beauty plays, played school to teach each other to read books, or competed with each other through demonstrations of paper-airplane folding prowess (Wohlwend, 2007c). However, in the last decade, newspapers have regularly reported the reduction of play time in U.S. kindergarten settings (Hemphill, 2006; Henig, 2008; Ohanian, 2002; Stewart, 2005) to make more time for more "academic" work. The erosion of play in early-childhood classrooms 
Reading Research Quarterly, 44(1)

2009

interferes with literacy teachers' responsibilities to help children read and respond to the powerful identity texts they encounter each day. In an increasingly visually complex and merchandise-packed environment, readers and writers must be able to competently manipulate and combine a complex mix of literacy practices with popular media, something the Disney Princess Players did regularly in their literacy play with Disney products.

Abbie's play-packed classroom was unusual, bucking a trend in U.S. public schools that "pushes down" first-grade curriculum and squeezes out time for play in kindergarten. In the first two years of the study, three of the kindergartens that were originally nominated as classrooms rich in literacy play changed dramatically. Play times were reduced or relegated to the end of the day after the school district mandated that all kindergartens implement daily individualized computerized instruction coordinated with a literacy block of scripted, whole-group word study and small-group reading instruction with the aim of eventually raising academic achievement measured through "annual yearly progress" rates for fourth-grade reading scores. Setting aside the dubious efficacy of an intensive phonics-based and experientially-deprived approach to overcoming the "fourth-grade slump" in reading comprehension scores (Snow, 2008), the schoolwide focus on test scores and standardized delivery of curriculum made teachers' provisions for lengthy play periods appear frivolous and risky.

In the current play-unfriendly climate, popular culture is especially suspect. Trendy media dolls for girls, such as Disney Princesses, Bratz, or Hannah Montana, are often restricted to show-and-tell periods, if not banned altogether. Jackie Marsh's (2006) work with preservice teachers showed that they resisted integrating popular-culture media into school curricula, believing media themes and toys to be inappropriate for school. But by banning Barbies and 
Reading Research Quarterly, 44(1)

2009

Bratz from our classrooms, we take ourselves out of the conversation, ceding our influence to corporations and missing opportunities for critique and engaged learning.

As teachers, we have allowed ourselves to be burdened with an increasingly earnest and accountable top-down curriculum, set in stone, while we have let Murdoch and Disney, like Pied Pipers, steal the hearts of children and monopolize pleasure. We have banished play from school and are selling the children to toy multinationals who are leading a merry trail of buy, buy, buy. There must be an alternative.... In disappearing from school, playfulness took with it the opportunities for personal projection and identification, the negotiating space where anything could be made to happen, which used to make curriculum friendly and resonant. (Pompe, 1996, pp. 118-119)

Unlike other early-childhood teachers in the classrooms that I visited, Abbie did not ban children's personal toys nor restrict them to recess periods or show-and-tell sessions. However, the recognition of the value of popular-media toys as means of significant meaning-making and social positioning raises concerns about teachers' willingness and abilities to mediate popularculture texts with gendered messages. Teachers are also subject to gendering, "subject to powerful discursive regimes mobilized by totems such as Barbie dolls or friction trucks brought to school by the children" (Reid, 1999, p. 171). As teachers and teacher-educators, we need to educate ourselves about popular culture and self-critically examine our own assumptions about media and gender so that we can help children critically read toys as texts.

Recognition of authoring/animating chains suggests that learners need sustained and regular blocks of time for literacy play, so that players and writers can return to projects to continue the improvisation/revision process. Authoring and animating chains suggest that play and literacy practices do not need to happen in the same time-space to enhance each other. 
Reading Research Quarterly, 44(1)

2009

Character development and plot twists that occurred during spontaneous doll play in the dollhouse ended up as story innovations in children's writings. Dramatic play had value that transcended the infusion of literacy materials into the housekeeping corner. The findings in this research challenge the marginalization of play in schools and revalue play as a means to incorporate popular culture and out-of-school literacies into school literacy practices. This multidimensional analysis of kindergartners' meaning-making and storying with Disney Princesses reaffirms the power of play as a transformative symbol system (Leland \& Harste, 1994) and points to the power of multimedia toys as catalysts and conduits for writing and drama in schools.

The challenge of tracking children's social practices and dynamic meanings of toys and artifacts presents new directions for literacy research. Research methods and models need to expand to enable analysis of the materiality of multimodal texts and the socially situated activity in the surrounding context. Critical sociocultural activity models capture multiple aspects of literacy practices and allow examination of social actors, practices, and discourses. The research design used here added a material dimension and a social semiotic lens to examine the design elements of toys and child-made artifacts situated in power relations. However, the concept of sedimented identities requires an expansion of theoretical models (Leander, 2002b) and research designs that can simultaneously consider multiple layers in multimodal texts and map discourses, identities, practices, and meanings across a sequence of time-spaces that weave in and out of pretend and real-world contexts. Multidimensional models and methods are needed to examine young children's out-of-school literacies and identity work with layered texts in emerging forms of digital doll play, such as online Disney Princesses and Barbie Girls MP3 players where digital doll play allows young girls to animate images (Richtel \& Stone, 2007), perhaps as precursors of 
Reading Research Quarterly, 44(1)

2009

zwinky sites for adolescents that enable users to design and animate digital avatars for use on

blogs and My Space sites. The proliferation of toy sites with social networks for young girls

(e.g., http://Barbie.everythinggirl.com, http://disney.go.com/princess/html/main_iframe.html)

suggests that these mergers of new literacies and doll play are important new spaces for young children to play, write, and transact identity texts.

\section{$\underline{\text { References }}$}

Baker-Sperry, L., \& Grauerholz, L. (2003). The pervasiveness and persistence of the feminine beauty ideal in children's fairy tales. Gender \& Society, 17(5), 711-726.

doi: $10.1177 / 0891243203255605$

Bakhtin, M.M. (1981). The dialogic imagination: Four essays. Austin, TX: University of Texas Press.

Barnes, D., \& Todd, F. (1995). Communication and learning revisited: Making meaning through talk. Portsmouth, NH: Boynton/Cook.

Bateson, G. (1972). A theory of play and fantasy. In G. Bateson (Ed.), Steps to an ecology of mind (pp. 177-193). San Francisco: Chandler. (Original work published 1955)

Bauman, R., \& Briggs, C.L. (1990). Poetics and performance as critical perspective on language and social life. Annual Review of Anthropology, 19(•••), 59-88.

Bell, E. (1995). Somatexts at the Disney Shop: Constructing the pentimentos of women's animated bodies. In E. Bell, L. Haas, \& L. Sell (Eds.), From mouse to mermaid: The politics of film, gender, and culture (pp. 107-124). Bloomington: Indiana University Press.

Blaise, M. (2005a). A feminist poststructuralist study of children "doing” gender in an urban kindergarten classroom. Early Childhood Research Quarterly, 20(1), 85-108. doi:10.1016/j.ecresq.2005.01.002 
Reading Research Quarterly, 44(1)

2009

Blaise, M. (2005b). Playing it straight: Uncovering gender discourses in the early childhood classroom. New York: Routledge.

Bloome, D., Carter, S.P., Christian, B.M., Otto, S., \& Shuart-Faris, N. (2005). Discourse analysis and the study of classroom language and literacy events: A microethnographic perspective. Mahwah, NJ: Erlbaum.

Boldt, G.M. (2002). Toward a reconceptualization of gender and power in an elementary classroom. Current Issues in Comparative Education, 5(1), 7-23.

Bourdieu, P. (1977). Outline of a theory of practice (R. Nice, Trans.). Cambridge, England: Cambridge University Press.

Bourdieu, P. (1986). The forms of capital. In J.G. Richardson (Ed.), Handbook of theory and research for the sociology of education (pp. 241-258). New York: Greenwood.

Brougère, G. (2006). Toy houses: A socio-anthropological approach to analysing objects. Visual Communication, 5(1), 5-24. doi:10.1177/1470357206060916

Buckingham, D. (1996). Moving images: Understanding children's emotional responses to television. Manchester, England: Manchester University Press.

Butler, J. (1993). Bodies that matter: On the discursive limits of "sex.” London: Routledge.

Calkins, L.M. (1986). The art of teaching writing. Portsmouth, NH: Heinemann.

Carrington, V. (2003). “I'm in a bad mood. Let's go shopping”: Interactive dolls, consumer culture and a 'glocalized' model of literacy. Journal of Early Childhood Literacy, 3(1), 83-98.

Christensen, L. (2000). Reading, writing, and rising up: Teaching about social justice and the power of the written word. Milwaukee, WI: Rethinking Schools.

Connell, R.W. (1987). Gender and power. Stanford, CA: Stanford University Press. 
Connell, R.W., \& Messerschmidt, J.W. (2005). Hegemonic masculinity. Gender \& Society, 19(6), 829859. doi:10.1177/0891243205278639

Corsaro, W.A. (1985). Friendship and peer culture in the early years. Norwood, NJ: Ablex.

Corsaro, W.A. (2003). We're friends right? Inside kids' culture. Washington, DC: Joseph Henry.

Davies, B. (1989). Frogs and snails and feminist tales: Preschool children and gender. Boston: Allen \& Unwin.

de Certeau, M. (1984). The practice of everyday life (S. Rendall, Trans.). Berkeley, CA: University of California Press.

Disney Consumer Products. (2007). Toys. Retrieved May 5, 2008, from https://licensing.disney.com/Home/display.jsp?contentId=dcp_home_ourbusinesses_toys\&forPri $\mathrm{nt}=$ false $\&$ language $=$ en $\&$ preview $=$ false $\&$ region $=0$

Do Rozario, R.A.C. (2004). The princess and the magic kingdom: Beyond nostalgia, the function of the Disney Princess. Women's Studies in Communications, 27(1), 34-59.

Dyson, A.H. (1993). Social worlds of children learning to write in an urban primary school. New York: Teachers College Press.

Dyson, A. H. (1997). Writing superheroes: Comtemporary childhood, popular culture, and classroom literacy. New York: Teachers College Press.

Dyson, A.H. (2003). The brothers and sisters learn to write: Popular literacies in childhood and school cultures. New York: Teachers College Press.

Dyson, A.H., \& Genishi, C. (2005). On the case: Approaches to language and literacy research. New York: Teachers College Press.

Elgas, M.P., Klein, E., Kantor, R., \& Fernie, D. (1988). Play and the peer culture: Play styles and object use. Journal of Research in Childhood Education, 3(2), 142-153. 
Reading Research Quarterly, 44(1)

2009

Engeström, Y. (1987). Learning by Expanding: An activity-theoretical approach to developmental research. Helskinki: Orienta-Konsultit.

Fernie, D.E., Kantor, R., \& Whaley, K.L. (1995). Learning from classroom ethnographies: Same places, different times. In J.A. Hatch (Ed.), Qualitative research in early childhood settings (pp. 155172). Westport, CT: Praeger.

Finders, M.J. (1997). Just girls: Hidden literacies and life in junior high. New York: Teachers College Press.

Foucault, M. (1978). The history of sexuality: Vol. 1. An introduction. New York: Random House.

Gee, J.P. (1996). Social linguistics and literacies: Ideology in discourses (2nd ed.). London: Taylor \& Francis.

Giroux, H.A. (1997). Are Disney movies good for your kids? In S.R. Steinberg \& J.L. Kincheloe (Eds.), Kinderculture: The corporate construction of childhood (pp. 53-67. Boulder, CO: Westview Press.

Giroux, H.A. (1999). The mouse that roared. Lanham, MD: Rowman \& Littlefield.

Goodman, K.S. (1994). Reading, writing, and written texts: A transactional sociopsycholinguistic view. In R.B. Ruddell, M.R. Ruddell, \& H. Singer (Eds.), Theoretical models and processes of reading (4th ed., pp. 1093-1130). Newark, DE: International Reading Association.

Graves, D.H. (1983). Writing: Teachers and children at work. Exeter, NH: Heinemann.

Haas, L. (1995). "Eighty-six the mother": Murder, matricide, and good mothers. In E. Bell, L. Haas, \& L. Sell (Eds.), From mouse to mermaid: The politics of film, gender, and culture (pp. 193-211). Bloomington: Indiana University Press.

Hartshorne, C., Weiss, P., \& Burks, A. W. (Eds.). (1998). Collected papers of Charles Sanders Peirce: Elements of logic (Vol. II). Cambridge, MA: Harvard University Press. 
Reading Research Quarterly, 44(1)

2009

Hemphill, C. (2006, July 26). In kindergarten playtime, a new meaning for "play.” The New York Times, p. B8.

Henig, R. M. (2008). Taking play seriously [Electronic Version]. The New York Times Magazine.

Retrieved October 1, 2008 from www.nytimes.com/2008/02/17/magazine/17play.html

Hilton, M. (1996). Manufacturing make-believe: Notes on the toy and media industry for children. In M. Hilton (Ed.), Potent fictions: Children's literacy and the challenge of popular culture (pp. 19-46). London: Routledge.

Hodge, R., \& Kress, G. (1988). Social semiotics. Ithaca, NY: Cornell University Press.

Holland, D., Lachicotte, W., Skinner, D., \& Cain, C. (1998). Identity and agency in cultural worlds. Cambridge, MA: Harvard University Press.

Iger, B. (2006). Walt Disney Company annual meeting of shareholders 2006. Retrieved December 9, 2007, from http://media.disney.go.com/investorrelations/presentations/060310_transcript.pdf

Ivanič, R. (2004). Discourses of writing and learning to write. Language and Education, 18(3), 220-245.

Jenkins, H. (Ed.). (1998). The children's culture reader. New York: New York University Press.

Jewitt, C., \& Kress, G. (Eds.). (2003). Multimodal literacy. New York: Peter Lang.

Jewitt, C., \& Oyama, R. (2001). Visual meaning: A social semiotic approach. In T. van Leeuwen \& C. Jewitt (Eds.), Handbook of visual analysis (pp. 134-156). London: Sage.

Kamler, B. (1994). Gender and genre in early writing. Linguistics and Education, 6(2), 153-182. doi:10.1016/0898-5898(94)90010-8

Kress, G. (1997). Before writing: Rethinking the paths to literacy. London: Routledge.

Kress, G. (2003a). Literacy in the new media age. London: Routledge. 
Reading Research Quarterly, 44(1)

2009

Kress, G. (2003b). Perspectives on making meaning: The differential principles and means of adults and children. In N. Hall, J. Larson, \& J. Marsh (Eds.), Handbook of early childhood literacy (pp. 154-166). London: Sage.

Kress, G., \& van Leeuwen, T. (1996). Reading images: The grammar of visual design. London: Routledge.

Lacroix, C. (2004). Images of animated Others: The Orientalization of Disney's cartoon heroines from The Little Mermaid to The Hunchback of Notre Dame. Popular Communication, 2(4), 213-229. Lave, J., \& Wenger, E. (1991). Situated learning: Legitimate peripheral participation. Cambridge, England: Cambridge University Press.

Leander, K.M. (2002a). Locating Latanya: The situated production of identity artifacts in classroom interaction. Research in the Teaching of English, 37(2), 198-250.

Leander, K.M. (2002b). Polycontextual construction zones: Mapping the expansion of schooled space and identity. Mind, Culture, and Activity, 9(3), 211-237. doi:10.1207/S15327884MCA0903_04

Leland, C.H., \& Harste, J.C. (1994). Multiple ways of knowing: Curriculum in a new key. Language Arts, 71(5), 337-345.

Lensmire, T.J. (1994). When children write: Critical re-visions of the writing workshop. New York: Teachers College Press.

Leont'ev, A. N. (1978). Activity, consciousness, and personality (M. J. Hall, Trans.). Englewood Cliffs, NJ: Prentice Hall.

Lewis, C., Enciso, P.E., \& Moje, E.B. (Eds.). (2007). Identity, agency, and power: Reframing sociocultural research on literacy. Mahwah, NJ: Erlbaum.

Loughlin, C.E., \& Martin, M.D. (1987). Supporting literacy: Developing effective learning environments. New York: Teachers College Press. 
Reading Research Quarterly, 44(1)

2009

Luke, A., Carrington, V., \& Kapitzke, C. (2003). Textbooks and early childhood literacy. In N. Hall, J. Larson, \& J. Marsh (Eds.), Handbook of early childhood literacy (pp. 249-257). London: Sage. MacGillivray, L., \& Martinez, A.M. (1998). Princesses who commit suicide: Primary children writing within and against gender stereotypes. Journal of Literacy Research, 30(1), 53-84.

Maclean, R. (1999). Constructing gendered subjectivities: Peer interactions in the first weeks of school. In B. Kamler \& J. Green (Eds.), Constructing gender and difference: Critical research perspectives on early childhood (pp. 71-96). Cresskill, NJ: Hampton.

Marsh, J. (1999). Batman and Batwoman go to school: Popular culture in the literacy curriculum. International Journal of Early Years Education, 7(2), 117-131.

Marsh, J. (2005). Ritual, performance and identity construction: Young children's engagement with popular cultural and media texts. In J. Marsh (Ed.), Popular culture, new media and digital literacy in early childhood (pp. 28-50). New York: RoutledgeFalmer.

Marsh, J. (2006). Popular culture in the literacy curriculum: A Bourdieuan analysis. Reading Research Quarterly, 41(2), 160-174. doi:10.1598/RRQ.41.2.1

Martens, P. (1996). I already know how to read: A child's view of literacy. Portsmouth, NH: Heinemann.

Merriam, S.B. (1998). Qualitative research and case study applications in education. San Francisco: Jossey-Bass.

Millard, E. (2003). Gender and early childhood literacy. In N. Hall, J. Larson, \& J. Marsh (Eds.), Handbook of early childhood literacy (pp. 22-33). London: Sage.

Mitchell, J.C. (1984). Typicality and the case study. In R.F. Ellen (Ed.), Ethnographic research: A guide to general conduct (pp. 238-241). London: Academic.

Munsch, R, (1980). [Illustrated by Martchenko, M.] The paper bag princess. Toronto: Annick. 
Reading Research Quarterly, 44(1)

2009

New London Group. (1996). A pedagogy of multiliteracies: Designing social futures. Harvard Educational Review, 66(1), 60-92.

Newkirk, T. (1989). More than stories: The range in children's writing. Portsmouth, NH: Heinemann.

Newkirk, T. (2002). Misreading masculinity: Boys, literacy, and popular culture. Portsmouth, NH: Heinemann.

Newkirk, T. (2007). Popular culture and writing development. Language Arts, 84(6), 539-548.

Newkirk, T., \& McClure, P. (1992). Listening in: Children talk about books (and other things). Portsmouth, NH: Heinemann.

Nichols, S. (2002). Parents' construction of their children as gendered, literate subjects: A critical discourse analysis. Journal of Early Childhood Literacy, 2(2), 123-144.

Noon, C. (2005). Iger's Disney courts princesses in huge campaign. Retrieved October 3, 2006, from http://www.forbes.com/facesinthenews/2005/10/03/disney-princesses-dvdscx_cn_1003autofacescan04.html

Norris, S., \& Jones, R.H. (2005). Discourse in action: Introducing mediated discourse analysis. London: Routledge.

Ohanian, S. (2002). What happened to recess and why are our children struggling in kindergarten? New York: McGraw-Hill.

Owocki, G., \& Goodman, Y.M. (2002). Kidwatching: Documenting children's literacy development. Portsmouth, NH: Heinemann.

Pompe, C. (1996). "But they're pink!"-“Who cares!”: Popular culture in the primary years. In M. Hilton (Ed.), Potent fictions: Children's literacy and the challenge of popular culture (pp. 92125). London: Routledge. 
Reading Research Quarterly, 44(1)

2009

Ray, K.W. (with Cleaveland, L.B.). (2004). About the authors: Writing workshop with our youngest writers. Portsmouth, NH: Heinemann.

Reid, J. (1999). Little women/little men: Gender, violence and embodiment in an early childhood

classroom. In B. Kamler \& J. Green (Eds.), Constructing gender and difference: Critical research perspectives on early childhood (pp. 167-190). Cresskill, NJ: Hampton.

Richards, T., \& Richards, L. (2002). NUD*IST 6. Doncaster, Victoria, Australia: QSR International.

Richtel, M., \& Stone, B. (2007, June 6). Logging on, playing dolls: For not-ready-for-MySpace girls, dress-up and diversions on the web. New York Times, [Electronic version]. Retrieved October 1, 2008, from

http://www.nytimes.com/2007/06/06/technology/06doll.html?_r=1\&oref=slogin\&pagewanted=al 1.

Rosenblatt, L.M. (1978). The reader, the text, the poem: The transactional theory of the literary work. Carbondale, IL: Southern Illinois University Press.

Rowe, D.W. (2008). Social contracts for writing: Negotiating shared understandings about text in the preschool years. Reading Research Quarterly, 43(1), 66-95. doi:10.1598/RRQ.43.1.5

Rowsell, J., \& Pahl, K. (2007). Sedimented identities in texts: Instances of practice. Reading Research Quarterly, 42(3), 388-404. doi:10.1598/RRQ.42.3.3

Sawyer, R.K. (1997). Pretend play as improvisation: Conversation in the preschool classroom. Norwood, NJ: Erlbaum.

Scollon, R. (2001a). Action and text: Towards an integrated understanding of the place of text in social (inter)action, mediated discourse analysis and the problem of social action. In R. Wodak \& M. Meyer (Eds.), Methods of critical discourse analysis (pp. 139-183). London: Sage.

Scollon, R. (2001b). Mediated discourse: The nexus of practice. London: Routledge. 
Reading Research Quarterly, 44(1)

2009

Scollon, R., \& Scollon, S.W. (2004). Nexus analysis: Discourse and the emerging internet. New York: Routledge.

Seiter, E. (1993). Sold separately: Children and parents in consumer culture. New Brunswick, NJ: Rutgers University Press.

Siegel, M. (1995). More than words: The generative power of transmediation for learning. Canadian Journal of Education, 20(4), 455-475. doi:10.2307/1495082

Siegel, M. (2006). Rereading the signs: Multimodal transformations in the field of literacy education. Language Arts, 84(1), 65-77.

Smith, P.K. (1988). Children's play and its role in early development: A reevaluation of the "play ethos." In A.D. Pellegrini (Ed.), Psychological bases for early education (pp. 207-226). Chichester, UK: Wiley.

Snow, C.E. (2008, May 3). Improving literacy outcomes: A time to act. Paper presented at the annual reading research conference of the International Reading Association, Atlanta, GA.

Steinberg, S.R., \& Kincheloe, J.L. (Eds.). (1997). Kinderculture: The corporate construction of childhood. Boulder, CO: Westview Press.

Stewart, T.L. (2005, November 4). For kindergartners, playtime is over: Full-day schedules, emphasis on learning create “new 1st grade.” Dallas Morning News, p. 6B. [Electronic Version] Retrieved October 2, 2008 from http://infoweb.newsbank.com/iwsearch/we/InfoWeb?p_product=AWNB\&p_theme=aggregated5\&p_action=doc\&p_docid=10DB 4CEEF89D6C68\&d_place=DMNB\&f_subsection=sMETRO\&f_issue=2005-1104\&f_publisher=

Street, B.V. (1995). Social literacies: Critical approaches to literacy in development, ethnography, and education. New York: Longman. 
Reading Research Quarterly, 44(1)

2009

Sutton-Smith, B. (1997). The ambiguity of play. Cambridge, MA: Harvard University Press.

Tobin, J. (2000). “Good guys don't wear hats”: Children's talk about the media. New York: Teachers College Press.

Tobin, J. (Ed.). (2004). Pikachu's global adventure: The rise and fall of Pokémon. Durham, NC: Duke University Press.

Toohey, K. (2000). Learning English at school: Identity, social relations, and classroom practice. Clevedon, England: Multilingual Matters.

van Leeuwen, T., \& Jewitt, C. (2001). Handbook of visual analysis. London: Sage.

Vygotsky, L.S. (1978). Mind in society: The development of higher psychological processes (M. Cole, V. John-Steiner, S. Scribner, \& E. Souberman, Eds. \& Trans.). Cambridge, MA: Harvard University Press. (Original work published in 1934)

Walkerdine, V. (1984). Someday my prince will come. In A. McRobbie \& M. Nava (Eds.), Gender and generation (pp. 162-184). London: Macmillan.

Wertsch, J.V. (1991). Voices of the mind: A sociocultural approach to mediated action. Cambridge, MA: Harvard University Press.

Whitmore, K.F., \& Goodman, Y.M. (1995). Transforming curriculum in language and literacy. In S. Bredekamp \& R. Teresa (Eds.), Reaching potentials: Transforming early childhood curriculum and assessment (Vol. 2, pp. 145-166). Washington, DC: National Association for the Education of Young Children.

Wohlwend, K.E. (2007a). Kindergarten as nexus of practice: A mediated discourse analysis of reading, writing, play, and design practices in an early literacy apprenticeship. Unpublished doctoral dissertation. Iowa City, Iowa: The University of Iowa. 
Wohlwend, K.E. (2007b). "More than a child's work": Framing teacher discourse about play.

Interactions: UCLA Journal of Education and Information Studies, 3(1). Retrieved March 8, 2007, from http://repositories.cdlib.org/gseis/interactions/vol3/iss1/art4

Wohlwend, K.E. (2007c). Playing to read and reading to play: A mediated discourse analysis of early literacy apprenticeship. In D.W. Rowe et al. (Eds.), (56th yearbook of the National Reading Conference, pp. 377-393). Chicago: National Reading Conference.

Wohlwend, K.E. (2008). From “What did I write?" to "Is this right?”: Invention, convention, and accountability in early literacy. The New Educator, 4(1), 43-63. doi:10.1080/15476880701829259

Wohlwend, K. E. (2008). "Are you guys girls?": Boys, Disney Princesses, and gender trouble in the playing/writing nexus. Manuscript submitted for publication.

Wohlwend, K.E. (In press). Dilemmas and discourses of learning to write: Assessment as a contested site. Language Arts, 86(5).

Wolfersberger, M.E., Reutzel, D.R., Sudweeks, R., \& Fawson, P.C. (2004). Developing and validating the Classroom Literacy Environmental Profile (CLEP): A tool for examining the "print richness" of early childhood and elementary classrooms. Journal of Literacy Research, 36(2), 211-272. 
Reading Research Quarterly, 44(1)

2009

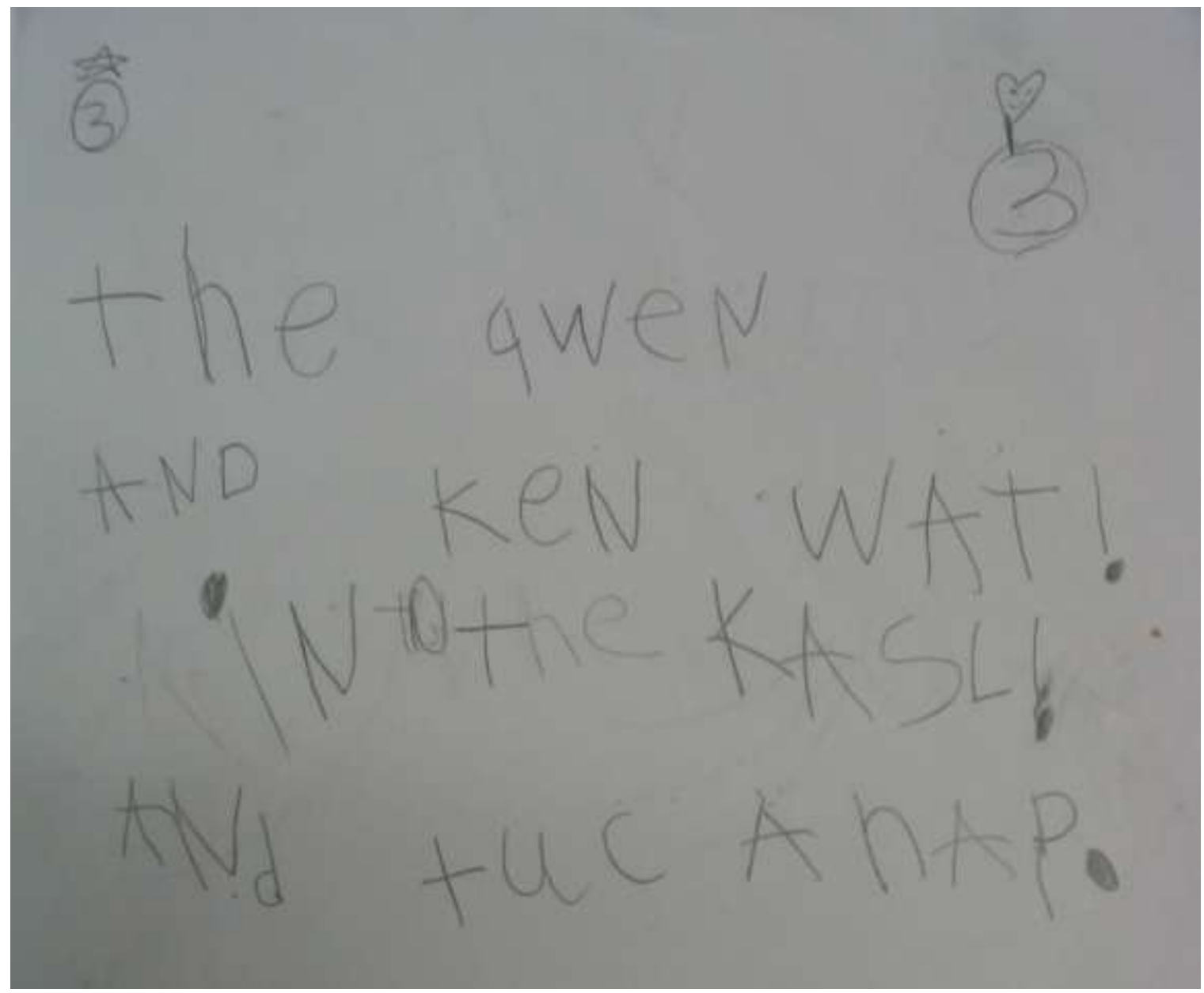

Figure 1. A Page of Mei Yu's Princess Puppet Show Script

Text: The queen and king went into the castle and took a nap.

Page 67 of 81 
Reading Research Quarterly, 44(1)

2009

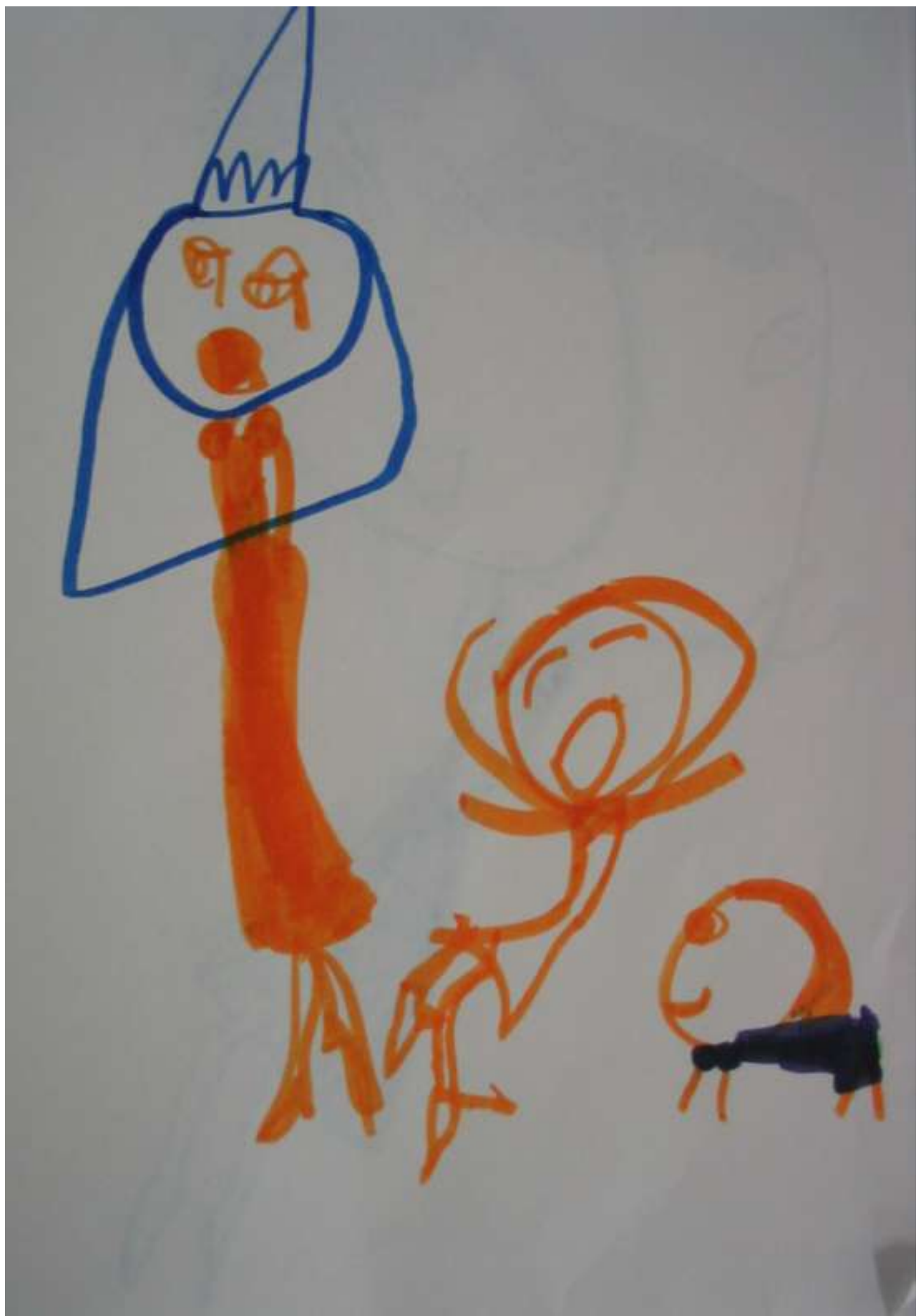

Figure 2. Zoe's Sleeping Beauty Book

Page 68 of 81 
Reading Research Quarterly, 44(1)

2009

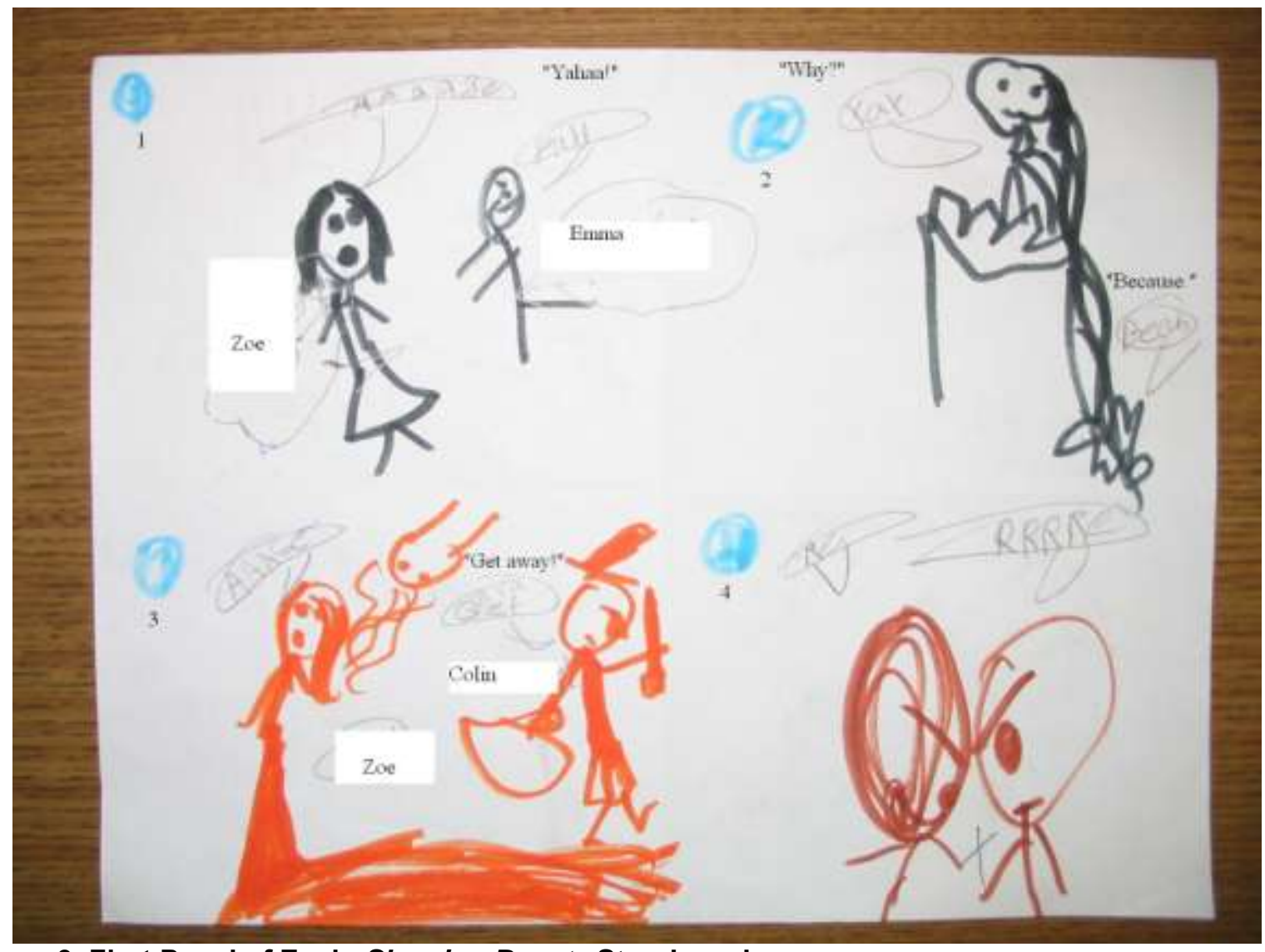

Figure 3. First Panel of Zoe's Sleeping Beauty Storyboard 
Reading Research Quarterly, 44(1)

2009

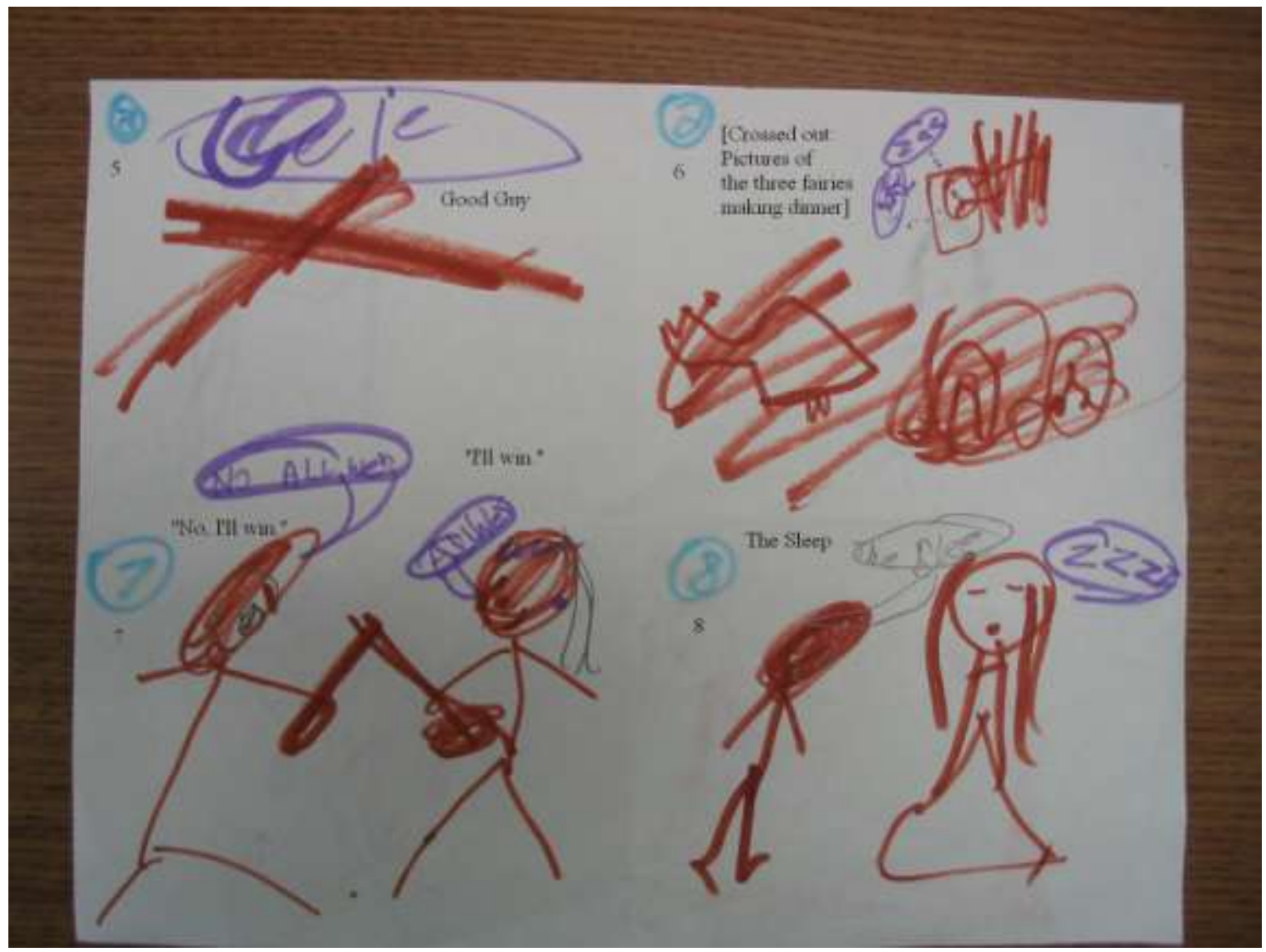

Figure 4. Second Panel of Zoe's Sleeping Beauty Storyboard 
Reading Research Quarterly, 44(1)

2009

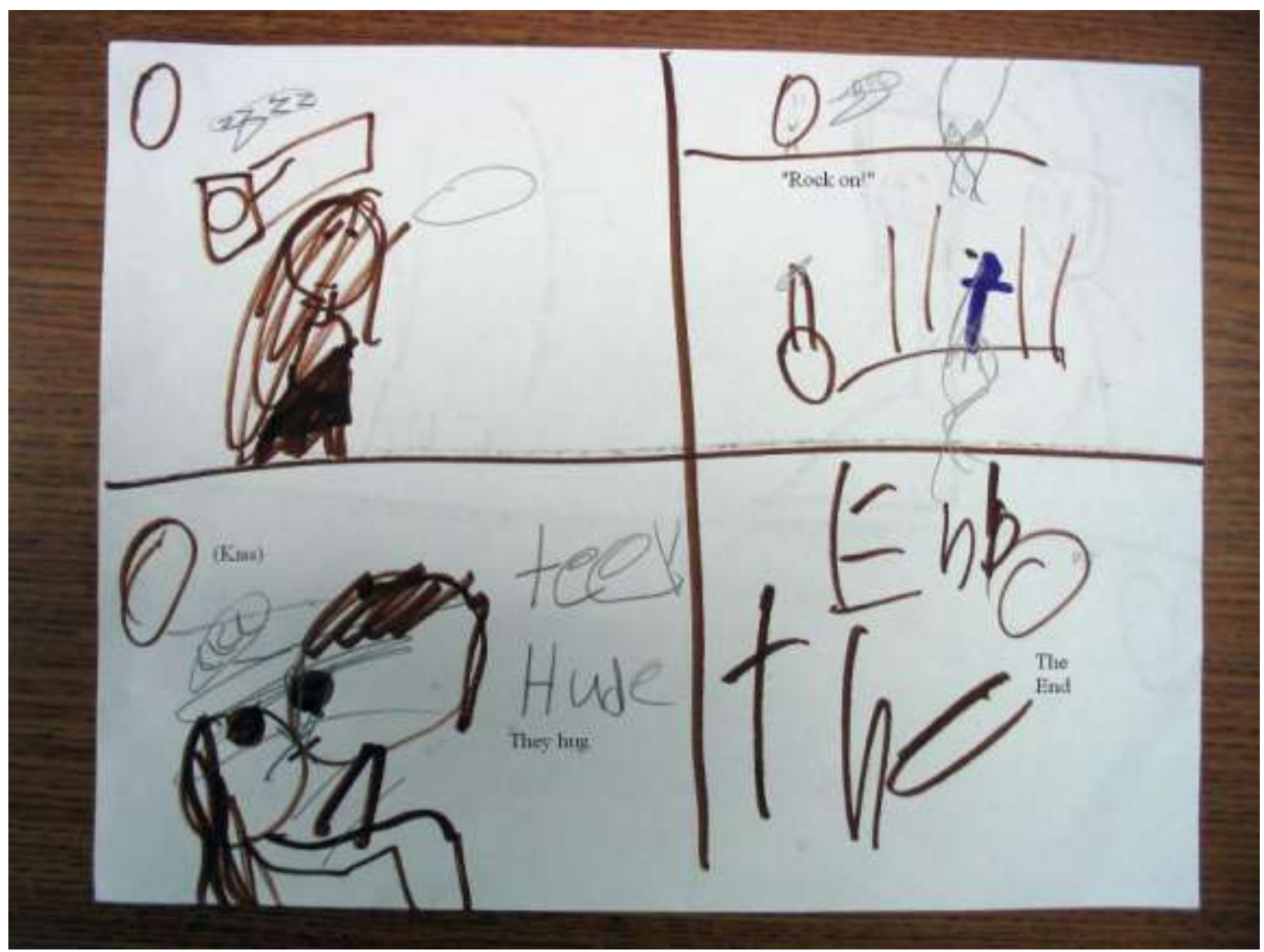

Figure 5. Third Panel of Zoe's Sleeping Beauty Storyboard 
Reading Research Quarterly, 44(1)

2009

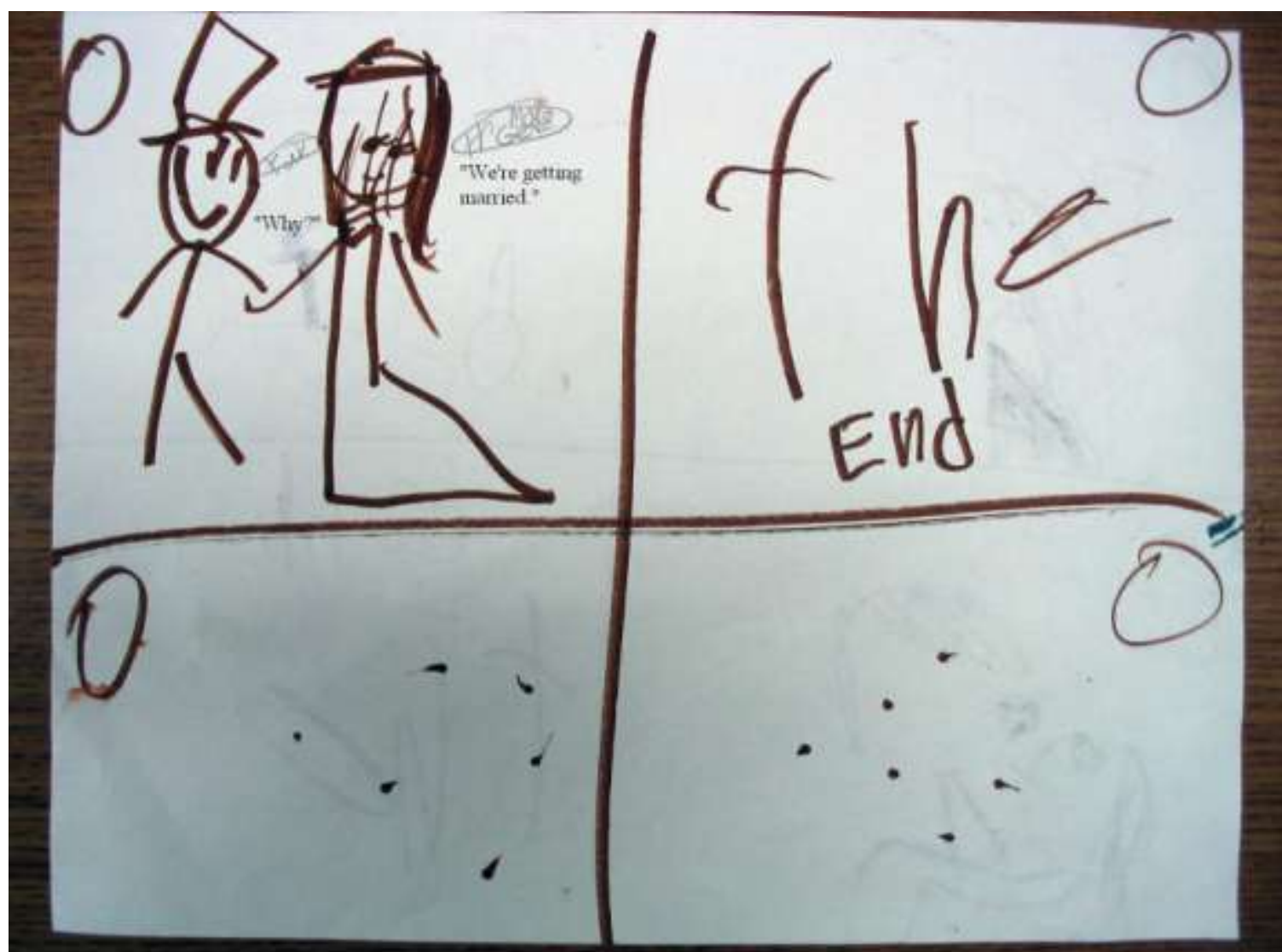

Figure

6. Fourth Panel of Zoe's Sleeping Beauty Storyboard 
Reading Research Quarterly, 44(1)

2009

Table 1. Material Features That Symbolize Disney Princess Characters

\begin{tabular}{|l|l|l|}
\hline Disney Princess character & Dress and dress color & Hair color and hairstyle \\
\hline Cinderella & Light blue ball gown & Light blonde, topknot bun \\
\hline Princess Aurora & Pink ball gown & Dark blonde, long, curly \\
\hline Belle (Beauty and the Beast) & Yellow ball gown & $\begin{array}{l}\text { Brunette, long wavy with } \\
\text { topknot }\end{array}$ \\
\hline Mulan & Silk gown & Black, long, straight \\
\hline Jasmine & Aqua top and harem pants & Black, long, wavy \\
\hline Ariel & $\begin{array}{l}\text { Shell bikini top with green } \\
\text { fishtail; lavender ball gown }\end{array}$ & Red, long, wavy \\
\hline Pocahontas & Tan buckskin tunic and skirt & Black, long, straight \\
\hline Snow White & Blue bodice with yellow skirt & Black, short, curly \\
\hline
\end{tabular}


Reading Research Quarterly, 44(1)

2009

Table 2. Play Improvisations and Storyboard Revisions by Scenes

\begin{tabular}{|c|c|c|c|c|c|}
\hline Scene & $\begin{array}{l}\text { Storyboard } \\
\text { Authoring } \\
\text { Planned Scenes }\end{array}$ & $\begin{array}{l}\text { Rehearsals } \\
\text { Animating } \\
\text { Improvisation }\end{array}$ & $\begin{array}{l}\text { Storyboard } \\
\text { Authoring } \\
\text { Revision }\end{array}$ & $\begin{array}{l}\text { Performance } \\
\text { Animating } \\
\text { Improvisation }\end{array}$ & $\begin{array}{l}\text { Storyboard } \\
\text { Authoring } \\
\text { Revision }\end{array}$ \\
\hline 1 & $\begin{array}{l}\text { Bad Fairy chases } \\
\text { Sleeping Beauty }\end{array}$ & & $\begin{array}{l}\text { Dialogue } \\
\text { added }\end{array}$ & & \\
\hline 2 & $\begin{array}{l}\text { Sleeping Beauty } \\
\text { (Rapunzel) in tower }\end{array}$ & & $\begin{array}{l}\text { Dialogue } \\
\text { added }\end{array}$ & & \\
\hline 3 & $\begin{array}{l}\text { Dragon attacks } \\
\text { Sleeping Beauty }\end{array}$ & & $\begin{array}{l}\text { Dialogue } \\
\text { added } \\
\text { Get Away! }\end{array}$ & $\begin{array}{l}\text { Prince confused; } \\
\text { Zoe decides to } \\
\text { replay Scene } 1\end{array}$ & \\
\hline 4 & $\begin{array}{l}\text { Prince \& Bad Fairy } \\
\text { fence }\end{array}$ & $\begin{array}{l}\text { Actors chase } \\
\text { each other }\end{array}$ & $\begin{array}{l}\text { Dialogue } \\
\text { added }\end{array}$ & & \\
\hline 5 & Good guy & Actor won't play & $\begin{array}{l}\text { Character label } \\
\text { added } \\
\text { Scene deleted }\end{array}$ & & \\
\hline 6 & $\begin{array}{l}\text { Fairies make dinner } \\
\text { while Sleeping } \\
\text { Beauty naps }\end{array}$ & $\begin{array}{l}\text { Actors busy and } \\
\text { don't want to } \\
\text { play; scene } \\
\text { deleted }\end{array}$ & $\begin{array}{l}\text { Scene deleted; } \\
\text { Sleeping } \\
\text { Beauty's nap } \\
\text { moved to } \\
\text { Scene } 9\end{array}$ & $\begin{array}{l}\text { Dinner scene } \\
\text { added back in; } \\
\text { Zoe plays fourth } \\
\text { fairy to lead } \\
\text { actors }\end{array}$ & \\
\hline 7 & $\begin{array}{l}\text { Prince \& Bad Fairy } \\
\text { fence }\end{array}$ & $\begin{array}{l}\text { Prince \& Dragon } \\
\text { chase each } \\
\text { other }\end{array}$ & $\begin{array}{l}\text { Dialogue } \\
\text { added, makes } \\
\text { sword as prop }\end{array}$ & $\begin{array}{l}\text { Zoe directs } \\
\text { Prince, fights } \\
\text { Dragon herself, } \\
\text { chains Dragon } \\
\text { to wall }\end{array}$ & $\begin{array}{l}\text { Hair added, } \\
\text { changing } \\
\text { Prince to } \\
\text { Princess }\end{array}$ \\
\hline 8 & $\begin{array}{l}\text { Bad Fairy puts spell } \\
\text { on Sleeping Beauty }\end{array}$ & & $\begin{array}{l}\text { Caption/Stage } \\
\text { direction } \\
\text { added: "The } \\
\text { Sleep" zzzz }\end{array}$ & & \\
\hline 9 & $\begin{array}{l}\text { Sleeping Beauty } \\
\text { sleeps }\end{array}$ & & $\begin{array}{l}\text { Sleeping scene } \\
\text { added in }\end{array}$ & $\begin{array}{l}\text { Awakens to } \\
\text { check storyboard } \\
\text { and direct Prince }\end{array}$ & \\
\hline 10 & $\begin{array}{l}\text { Dragon killed; } \\
\text { Prince cheers }\end{array}$ & & & $\begin{array}{l}\text { Dragon chained } \\
\text { up by Zoe, } \\
\text { forced to attend }\end{array}$ & $\begin{array}{l}\text { Dialogue } \\
\text { added; } \\
\text { Dragon revived }\end{array}$ \\
\hline
\end{tabular}


Reading Research Quarterly, 44(1)

2009

\begin{tabular}{|l|l|l|l|l|l|}
\hline & & & & wedding \\
\hline 11 & Prince kisses & & $\begin{array}{l}\text { Kiss changed } \\
\text { to hug; stage } \\
\text { direction added }\end{array}$ & & \\
\hline 12 & The End & & Moved after & & \\
\hline 13 & Wedding & wedding & & Dialogue \\
& & & Scene added & & added \\
\hline 14 & The End & & & & \\
\hline
\end{tabular}


Reading Research Quarterly, 44(1)

2009

Table 3. Transcript of Scene 3 in Sleeping Beauty Play: Turns 1-17

\begin{tabular}{|c|c|c|c|c|c|c|c|c|}
\hline Turn & Time & Action/Context & $\begin{array}{l}\text { Talk at } \\
\text { each turn }\end{array}$ & $\begin{array}{l}\text { Transformati } \\
\text { on: } \\
\text { Classroom } \\
\text { identity }\end{array}$ & $\begin{array}{l}\text { Transformati } \\
\text { on: } \\
\text { Play identity }\end{array}$ & $\begin{array}{l}\text { Practices: } \\
\text { Play and writing }\end{array}$ & $\begin{array}{l}\text { Effect on } \\
\text { meaning: } \\
\text { Script text }\end{array}$ & $\begin{array}{l}\text { Effect on } \\
\text { participation }\end{array}$ \\
\hline 1 & $\begin{array}{ll}10 & 10 \\
: 04: 35 & \end{array}$ & $\begin{array}{l}\text { Zoe is directing } \\
\text { and playing the } \\
\text { lead in the } \\
\text { Sleeping Beauty } \\
\text { play that she has } \\
\text { written. She } \\
\text { refers to her } \\
\text { storyboard to } \\
\text { locate the next } \\
\text { scene. }\end{array}$ & $\begin{array}{l}\text { The next } \\
\text { scene is... }\end{array}$ & & $\begin{array}{l}\text { Author, } \\
\text { animator, and } \\
\text { lead actor }\end{array}$ & $\begin{array}{l}\text { Animating by } \\
\text { directive }\end{array}$ & $\begin{array}{l}\text { Transition } \\
\text { between } \\
\text { scenes; text } \\
\text { suspended }\end{array}$ & $\begin{array}{l}\text { Zoe's role as } \\
\text { playwright/ } \\
\text { animator } \\
\text { establishes } \\
\text { her leader } \\
\text { role. She has } \\
\text { chosen the } \\
\text { players; their } \\
\text { positions as } \\
\text { characters } \\
\text { require them } \\
\text { to follow her } \\
\text { directions }\end{array}$ \\
\hline 2 & :04:39 & $\begin{array}{l}\text { Zoe shouts to the } \\
\text { cast clustered } \\
\text { around the } \\
\text { bicycle racks. }\end{array}$ & OK! & $\begin{array}{l}\text { Zoe as } \\
\text { animator }\end{array}$ & & & Play resumes & $\begin{array}{l}\text { Everyone } \\
\text { attends to } \\
\text { Zoe }\end{array}$ \\
\hline 3 & :04:39 & $\begin{array}{l}\text { She points to } \\
\text { Matt and then } \\
\text { turns her back to } \\
\text { him, arms rigid at }\end{array}$ & $\begin{array}{l}\text { You're } \\
\text { blowing } \\
\text { steam on } \\
\text { me behind }\end{array}$ & $\begin{array}{l}\text { Zoe as } \\
\text { animator and } \\
\text { actor, Matt as } \\
\text { actor }\end{array}$ & $\begin{array}{l}\text { Zoe as } \\
\text { Princess, } \\
\text { Matt as } \\
\text { Dragon }\end{array}$ & $\begin{array}{l}\text { Animating, } \\
\text { Enacting }\end{array}$ & $\begin{array}{l}\text { Scene 3: The } \\
\text { Dragon } \\
\text { threatens the } \\
\text { Princess }\end{array}$ & $\begin{array}{l}\text { Zoe directs } \\
\text { Matt }\end{array}$ \\
\hline
\end{tabular}


Reading Research Quarterly, 44(1) 2009

\begin{tabular}{|c|c|c|c|c|c|c|c|c|}
\hline & & $\begin{array}{l}\text { her sides. She } \\
\text { continues to } \\
\text { watch him by } \\
\text { looking back over } \\
\text { her shoulder. }\end{array}$ & me. & & & & & \\
\hline 4 & $: 04: 42$ & $\begin{array}{l}\text { Matt puffs in one } \\
\text { continuous } \\
\text { motion at her } \\
\text { neck and back, } \\
\text { slightly wiggling } \\
\text { his head back } \\
\text { and forth. }\end{array}$ & & Matt as actor & $\begin{array}{l}\text { Matt as } \\
\text { attacking } \\
\text { Dragon; Zoe } \\
\text { as Princess }\end{array}$ & Enacting & $\begin{array}{l}\text { In character } \\
\text { action, } \\
\text { consistent } \\
\text { with script }\end{array}$ & $\begin{array}{l}\text { Complies } \\
\text { with Zoe's } \\
\text { directive }\end{array}$ \\
\hline 5 & $\begin{array}{ll}10 & 10 \\
: 04: 44 & \end{array}$ & $\begin{array}{l}\text { Colin steps next } \\
\text { to Matt and puffs } \\
\text { out his cheeks as } \\
\text { if to blow steam. }\end{array}$ & Now me. & $\begin{array}{l}\text { Colin as } \\
\text { improvising } \\
\text { author/player }\end{array}$ & $\begin{array}{l}\text { Bid for new } \\
\text { role as } \\
\text { second } \\
\text { Dragon }\end{array}$ & $\begin{array}{l}\text { Authoring by } \\
\text { metaplay } \\
\text { directive }\end{array}$ & $\begin{array}{l}\text { Challenges } \\
\text { authority of } \\
\text { text with } \\
\text { innovation }\end{array}$ & $\begin{array}{l}\text { Bids for turn } \\
\text { to play } \\
\text { according to } \\
\text { own } \\
\text { improvised } \\
\text { script }\end{array}$ \\
\hline 6 & $: 04: 47$ & $\begin{array}{l}\text { Zoe points at } \\
\text { Colin. }\end{array}$ & $\begin{array}{l}\text { No, not } \\
\text { you. You're } \\
\text { the Prince. } \\
\text { You say, } \\
\text { "Get away." }\end{array}$ & $\begin{array}{l}\text { Asserts Zoe's } \\
\text { authority as } \\
\text { animator and } \\
\text { author }\end{array}$ & $\begin{array}{l}\text { Restates play } \\
\text { identity: } \\
\text { Colin as } \\
\text { Prince }\end{array}$ & $\begin{array}{l}\text { Animating by } \\
\text { metaplay } \\
\text { directive }\end{array}$ & $\begin{array}{l}\text { Establishes } \\
\text { authority of } \\
\text { text by citing } \\
\text { assigned role } \\
\text { and line from } \\
\text { script }\end{array}$ & $\begin{array}{l}\text { Rejects bid } \\
\text { for turn to } \\
\text { play. Implicit } \\
\text { directive to } \\
\text { comply with } \\
\text { script }\end{array}$ \\
\hline
\end{tabular}


Reading Research Quarterly, 44(1)

2009

\begin{tabular}{|c|c|c|c|c|c|c|c|c|}
\hline 7 & $: 04: 50$ & $\begin{array}{l}\text { Colin looks at } \\
\text { Matt, lowers his } \\
\text { head and leans } \\
\text { toward Matt. }\end{array}$ & "Get away." & $\begin{array}{l}\text { Accepts } \\
\text { Zoe's } \\
\text { authority as } \\
\text { leader }\end{array}$ & $\begin{array}{l}\text { Colin as } \\
\text { defending } \\
\text { Prince, Matt } \\
\text { as Dragon } \\
\text { who is a } \\
\text { threat }\end{array}$ & Enacting & $\begin{array}{l}\text { Prince } \\
\text { commands } \\
\text { Dragon to } \\
\text { leave } \\
\text { Complies } \\
\text { with text's } \\
\text { wording }\end{array}$ & $\begin{array}{l}\text { Complies } \\
\text { with Zoe's } \\
\text { directive }\end{array}$ \\
\hline 8 & $\begin{array}{ll}10 & 10 \\
: 04: 51 & \end{array}$ & $\begin{array}{l}\text { Zoe laughs and } \\
\text { points at Matt, } \\
\text { then herself. }\end{array}$ & $\begin{array}{l}\text { No! Not to } \\
\text { him! [To] } \\
\text { Me! }\end{array}$ & $\begin{array}{l}\text { Zoe uses her } \\
\text { authority as } \\
\text { author to } \\
\text { clarify the } \\
\text { meaning of } \\
\text { the text. }\end{array}$ & $\begin{array}{l}\text { Colin as } \\
\text { Prince telling } \\
\text { Princess to } \\
\text { escape, Zoe } \\
\text { as Princess } \\
\text { who needs to } \\
\text { flee. }\end{array}$ & $\begin{array}{l}\text { Animating by } \\
\text { metaplay } \\
\text { directive; } \\
\text { authoring }\end{array}$ & $\begin{array}{l}\text { Princ } \\
\text { e warns } \\
\text { Princess; } \\
\text { tells her to } \\
\text { run; clarifies } \\
\text { the implicit } \\
\text { meaning of } \\
\text { the text not } \\
\text { recorded in } \\
\text { the words. }\end{array}$ & $\begin{array}{l}\text { Rejects } \\
\text { Colin's } \\
\text { compliant } \\
\text { action. } \\
\text { Implicit } \\
\text { directive to } \\
\text { repeat action } \\
\text { in a revised } \\
\text { way. }\end{array}$ \\
\hline 9 & :04:53 & $\begin{array}{l}\text { Colin straightens } \\
\text { and stands still, } \\
\text { looks at Zoe, } \\
\text { puzzled. }\end{array}$ & $\begin{array}{l}\text { [Implicit } \\
\text { request for } \\
\text { help by } \\
\text { gaze at } \\
\text { leader } \\
\text { combined } \\
\text { with } \\
\text { inaction] }\end{array}$ & $\begin{array}{l}\text { Colin as } \\
\text { actor; Zoe as } \\
\text { animator }\end{array}$ & Play stalls & & $\begin{array}{l}\text { Discrepancy } \\
\text { between text } \\
\text { and two } \\
\text { contexts: } \\
\text { Conflict in } \\
\text { implicit } \\
\text { meanings of } \\
\text { words "Get } \\
\text { away!" }\end{array}$ & $\begin{array}{l}\text { No takeup of } \\
\text { directive to } \\
\text { repeat action. }\end{array}$ \\
\hline
\end{tabular}


Reading Research Quarterly, 44(1)

2009

\begin{tabular}{|c|c|c|c|c|c|c|c|c|}
\hline 10 & $: 04: 57$ & $\begin{array}{l}\text { Theresa steps in } \\
\text { between Zoe and } \\
\text { Colin and repeats } \\
\text { Zoe's finger } \\
\text { pointing } \\
\text { demonstration. } \\
\text { She smiles at him } \\
\text { and gestures for } \\
\text { him to "go ahead" } \\
\text { by sweeping her } \\
\text { hands forward } \\
\text { toward Zoe and } \\
\text { Matt. }\end{array}$ & $\begin{array}{l}\text { [Say] "Get } \\
\text { away!" }\end{array}$ & $\begin{array}{l}\text { Theresa as } \\
\text { cooperative } \\
\text { friend; Zoe as } \\
\text { leader }\end{array}$ & $\begin{array}{l}\text { Colin as } \\
\text { Prince }\end{array}$ & Animating & $\begin{array}{l}\text { Reinforces } \\
\text { explicit } \\
\text { wording but } \\
\text { does not } \\
\text { address the } \\
\text { confusion of } \\
\text { two implicit } \\
\text { meanings }\end{array}$ & $\begin{array}{l}\text { Affirms Zoe's } \\
\text { directive; } \\
\text { Supports } \\
\text { Colin with } \\
\text { encourageme } \\
\text { nt }\end{array}$ \\
\hline 11 & $: 05: 00$ & $\begin{array}{l}\text { Zoe rushes } \\
\text { toward Theresa } \\
\text { and shakes her } \\
\text { finger at her. }\end{array}$ & $\begin{array}{l}\text { You're } \\
\text { not- }\end{array}$ & $\begin{array}{l}\text { Zoe as } \\
\text { animator, } \\
\text { Theresa as } \\
\text { actor } \\
\text { usurping } \\
\text { animator role }\end{array}$ & $\begin{array}{l}\text { Theresa as } \\
\text { Third Fairy } \\
\text { telling Prince } \\
\text { to get away }\end{array}$ & Directing & $\begin{array}{l}\text { Unwarranted } \\
\text { appearance } \\
\text { of character } \\
\text { not in scene }\end{array}$ & $\begin{array}{l}\text { Rejects } \\
\text { Theresa's } \\
\text { support }\end{array}$ \\
\hline 12 & $\begin{array}{l}10 \\
: 05: 01\end{array}$ & $\begin{array}{l}\text { Zoe looks back at } \\
\text { Colin, as Theresa } \\
\text { tells Colin with a } \\
\text { sweeping } \\
\text { gesture, palm up, } \\
\text { outward toward } \\
\text { Zoe, . }\end{array}$ & $\begin{array}{l}\text { Say it } \\
\text { again, "Get } \\
\text { away." }\end{array}$ & $\begin{array}{l}\text { Theresa as } \\
\text { animator, } \\
\text { Colin as actor }\end{array}$ & $\begin{array}{l}\text { Theresa out } \\
\text { of character }\end{array}$ & Animating & $\begin{array}{l}\text { Focus on } \\
\text { verbalization } \\
\text { of surface } \\
\text { text, not } \\
\text { meaning }\end{array}$ & $\begin{array}{l}\text { Reaffirms } \\
\text { Zoe's } \\
\text { directive; } \\
\text { Supports } \\
\text { Colin with } \\
\text { encourageme } \\
\text { nt }\end{array}$ \\
\hline
\end{tabular}


Reading Research Quarterly, 44(1)

2009

\begin{tabular}{|c|c|c|c|c|c|c|c|c|}
\hline 13 & $\begin{array}{l}10 \\
: 05: 02\end{array}$ & $\begin{array}{l}\text { Zoe gives } \\
\text { Theresa a slight } \\
\text { push and points a } \\
\text { finger at her. }\end{array}$ & Be quiet. & $\begin{array}{l}\text { Zoe as } \\
\text { animator; } \\
\text { Theresa as } \\
\text { competing } \\
\text { animator }\end{array}$ & $\begin{array}{l}\text { Theresa out } \\
\text { of character }\end{array}$ & & $\begin{array}{l}\text { Play } \\
\text { suspended }\end{array}$ & $\begin{array}{l}\text { Directive with } \\
\text { aggressive } \\
\text { action, } \\
\text { conflict }\end{array}$ \\
\hline 14 & :05:05 & $\begin{array}{l}\text { The teacher } \\
\text { associate steps } \\
\text { closer. Zoe looks } \\
\text { up guiltily and } \\
\text { opens her mouth } \\
\text { to explain, but the } \\
\text { teacher associate } \\
\text { talks to Colin. }\end{array}$ & $\begin{array}{l}\text { Say "Get } \\
\text { away." }\end{array}$ & $\begin{array}{l}\text { Colin as } \\
\text { obedient } \\
\text { student; } \\
\text { Teacher } \\
\text { associate as } \\
\text { animator and } \\
\text { adult in } \\
\text { authority }\end{array}$ & $\begin{array}{l}\text { Reinforces } \\
\text { Zoe's } \\
\text { authority as } \\
\text { child } \\
\text { animator, } \\
\text { Colin's } \\
\text { compliance } \\
\text { as actor }\end{array}$ & Animating & $\begin{array}{l}\text { Teacher } \\
\text { legitimates } \\
\text { explicit } \\
\text { wording, fails } \\
\text { to } \\
\text { see/address } \\
\text { confusion } \\
\text { over implicit } \\
\text { meanings; } \\
\text { forestalls } \\
\text { further } \\
\text { discussion of } \\
\text { meanings. }\end{array}$ & $\begin{array}{l}\text { Adult's } \\
\text { directive } \\
\text { prevents } \\
\text { further } \\
\text { conflict; } \\
\text { enforces } \\
\text { Colin's } \\
\text { compliance; } \\
\text { reinforces } \\
\text { Zoe's role as } \\
\text { leader; } \\
\text { ignores } \\
\text { Theresa's } \\
\text { contribution. }\end{array}$ \\
\hline 15 & :05:08 & $\begin{array}{l}\text { Colin crouches } \\
\text { down, } \\
\text { menacingly with } \\
\text { clawing hand } \\
\text { motions, reaches } \\
\text { forward and } \\
\text { growls the words } \\
\text { at Zoe }\end{array}$ & "Get away." & Colin as actor & $\begin{array}{l}\text { Colin as } \\
\text { Prince } \\
\text { attacking } \\
\text { Princess }\end{array}$ & Enacting & $\begin{array}{l}\text { Text } \\
\text { misinterprete } \\
\text { d } \\
\text { /transformed: } \\
\text { Prince } \\
\text { threatens } \\
\text { Princess }\end{array}$ & $\begin{array}{l}\text { Colin } \\
\text { performs } \\
\text { compliantly; } \\
\text { gives up } \\
\text { sense- } \\
\text { making }\end{array}$ \\
\hline
\end{tabular}


Reading Research Quarterly, 44(1)

2009

\begin{tabular}{|c|c|c|c|c|c|c|c|c|}
\hline 16 & $: 05: 14$ & $\begin{array}{l}\text { Zoe gives up on } \\
\text { directing Colin } \\
\text { and runs away } \\
\text { from him toward } \\
\text { the grassy } \\
\text { playground and } \\
\text { shouts behind } \\
\text { her, pointing to } \\
\text { Emma. }\end{array}$ & $\begin{array}{l}\text { OK! Now, } \\
\text { Emma, } \\
\text { chase me } \\
\text { again! }\end{array}$ & $\begin{array}{l}\text { Zoe as } \\
\text { animator, } \\
\text { Emma as } \\
\text { actor }\end{array}$ & $\begin{array}{l}\text { Zoe as } \\
\text { Princess, } \\
\text { Emma as } \\
\text { Bad Guy }\end{array}$ & $\begin{array}{l}\text { Authoring, } \\
\text { Animating, } \\
\text { Enacting }\end{array}$ & $\begin{array}{l}\text { Transforms } \\
\text { text by } \\
\text { adding new } \\
\text { scene that } \\
\text { replays } \\
\text { Scene } 1 \text { with } \\
\text { original } \\
\text { threat. } \\
\text { Clarifies Bad } \\
\text { Guy as } \\
\text { threat, rather } \\
\text { than Prince. }\end{array}$ & $\begin{array}{l}\text { Zoe gives up } \\
\text { sense- } \\
\text { making with } \\
\text { Colin; } \\
\text { resumes } \\
\text { directing and } \\
\text { engages } \\
\text { Emma }\end{array}$ \\
\hline 17 & $: 05: 20$ & $\begin{array}{l}\text { Emma chases } \\
\text { Zoe across the } \\
\text { grass and back to } \\
\text { the sidewalk in a } \\
\text { wide arc. }\end{array}$ & & $\begin{array}{l}\text { Zoe as actor, } \\
\text { Emma as } \\
\text { actor }\end{array}$ & $\begin{array}{l}\text { Zoe as } \\
\text { Princess, } \\
\text { Emma as } \\
\text { Bad Guy }\end{array}$ & Enacting & $\begin{array}{l}\text { Text } \\
\text { transformed } \\
\text { with meaning } \\
\text { restored by } \\
\text { addition of } \\
\text { replayed } \\
\text { scene }\end{array}$ & \\
\hline
\end{tabular}

